\title{
Ratings of age of acquisition of 299 words across 25 languages: Is there a cross-linguistic order of words?
}

\author{
Magdalena Luniewska ${ }^{1,33}$ • Ewa Haman ${ }^{1}$ - Sharon Armon-Lotem ${ }^{2}$. \\ Bartlomiej Etenkowski $^{3}$ • Frenette Southwood ${ }^{4}$ - Darinka Anđelković ${ }^{5}$ - Elma Blom ${ }^{6}$. \\ Tessel Boerma ${ }^{6}$ - Shula Chiat $^{7}$ - Pascale Engel de Abreu ${ }^{8}$ - Natalia Gagarina ${ }^{9}$. \\ Anna Gavarró ${ }^{10}$ • Gisela Håkansson ${ }^{11}$ • Tina Hickey ${ }^{12}$ • Kristine Jensen de López ${ }^{13}$. \\ Theodoros Marinis $^{14}$ - Maša Popović ${ }^{5}$ - Elin Thordardottir ${ }^{15}$ - Agnè Blažienè ${ }^{16}$.

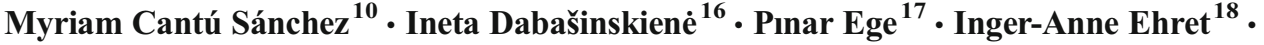 \\ Nelly-Ann Fritsche ${ }^{19}$ - Daniela Gatt ${ }^{20}$ • Bibi Janssen ${ }^{21}$ - Maria Kambanaros ${ }^{22}$. \\ Svetlana Kapalková $^{23}$ • Bjarke Kronqvist ${ }^{13}$ - Sari Kunnari ${ }^{24}$ - Chiara Levorato ${ }^{25}$. $^{2}$ \\ Olga Nenonen $^{26} \cdot$ Siobhán Nic Fhlannchadha ${ }^{12} \cdot$ Ciara O'Toole $^{27} \cdot$ Kamila Polišenská $^{28}$. \\ Barbara Pomiechowska $^{29}$ • Natalia Ringblom ${ }^{30}$ • Tanja Rinker ${ }^{19}$ - Maja Roch ${ }^{25}$. \\ Maja Savić $^{5}$ • Daniela Slančová ${ }^{31} \cdot$ Ianthi Maria Tsimpli $^{32} \cdot$ Özlem Ünal-Logacev $^{17}$
}

Electronic supplementary material The online version of this article (doi:10.3758/s13428-015-0636-6) contains supplementary material, which is available to authorized users.

Magdalena Łuniewska

magdalena.luniewska@psych.uw.edu.pl

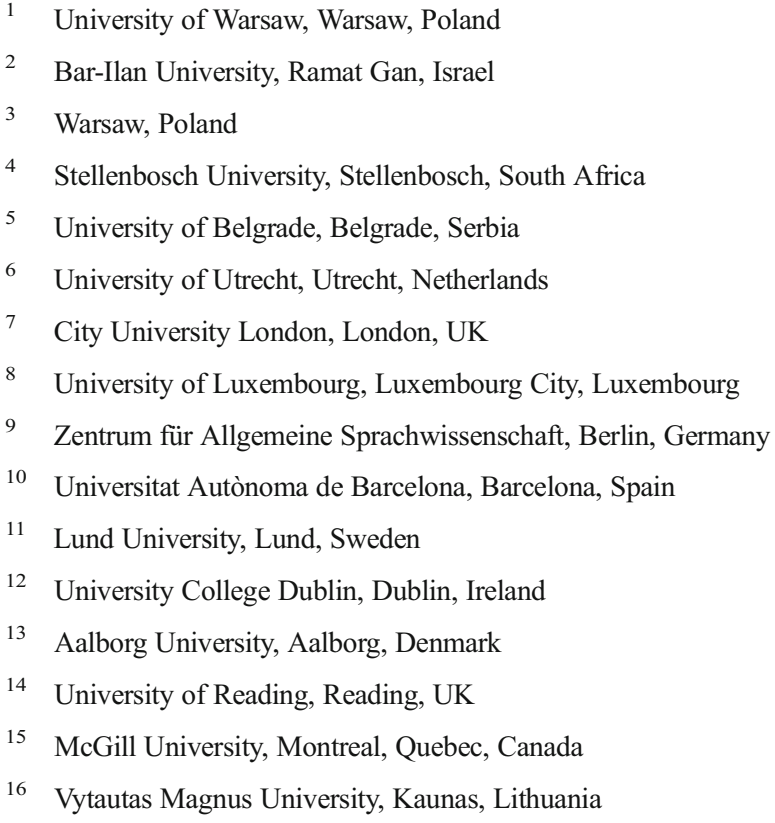


Abstract We present a new set of subjective age-ofacquisition (AoA) ratings for 299 words (158 nouns, 141 verbs) in 25 languages from five language families (AfroAsiatic: Semitic languages; Altaic: one Turkic language: Indo-European: Baltic, Celtic, Germanic, Hellenic, Slavic, and Romance languages; Niger-Congo: one Bantu language; Uralic: Finnic and Ugric languages). Adult native speakers reported the age at which they had learned each word. We present a comparison of the AoA ratings across all languages by contrasting them in pairs. This comparison shows a consistency in the orders of ratings across the 25 languages. The data were then analyzed (1) to ascertain how the demographic characteristics of the participants influenced AoA estimations and (2) to assess differences caused by the exact form of the target question (when did you learn vs. when do children learn this word); (3) to compare the ratings obtained in our study to those of previous studies; and (4) to assess the validity of our study by comparison with quasi-objective AoA norms derived from the MacArthur-Bates Communicative Development Inventories (MB-CDI). All 299 words were judged as being acquired early (mostly before the age of 6 years). AoA ratings were associated with the raters' social or language status, but not with the raters' age or education. Parents reported words as being learned earlier, and bilinguals reported learning them later. Estimations of the age at which children learn the words revealed significantly lower ratings of AoA. Finally, comparisons with previous AoA and MB-CDI norms support the validity of the present estimations. Our AoA ratings are available for research or other purposes.

Keywords Words $\cdot$ Age of acquisition $\cdot$ AoA . Cross-linguistic comparison $\cdot$ Subjective ratings

A body of research suggests that words acquired earlier in life are processed faster than words learned later. This effect, called the age-of-acquisition (henceforth, AoA) effect, has been observed in various lexical tasks over the last 40 years (Juhasz, 2005) in both children and adults. AoA effect plays a significant role in word processing and should be used as a control factor in experiments in which different word stimuli are used. The goal of this article is to provide fully comparable subjective ratings of AoA obtained with the very same procedure for the same set of words, both nouns and verbs, across 25 languages from five different language families. To the best of our knowledge, this is the very first study comprising such a number of diverse languages. Previous studies were typically conducted in one language only or in a pair of languages. Opportunities for cross-linguistic comparisons of previous studies' results were diminished by the fact that these studies also differed in terms of the list of words used and in other significant details of their procedures. In the present study, we also considered the potential effects of the participants' age, education, number of languages known, and parental status on the AoA ratings.

\section{AoA effect}

A large number of studies have examined AoA, and most of the representative studies show an effect of AoA on different tasks performed by children and adults. These are summarized by type of task and language in Table 1. To date, the tasks in which the AoA effect has been evidenced for common words have been picture naming, word naming, object recognition, word category decision, semantic classification, associations, lexical decision, orthographic decision, and sentence reading. It is notable that most of the available studies to date have focused on AoA in a single language.

Most of the studies were performed with adults, although three studies report child data (from 3 to 10 years of age) and two studies had teenagers as participants (from 11 to 17 years of age). In the majority of the studies with adults, only students were participants (e.g., Baumeister, 1984; Bonin, Fayol, \& Chalard, 2001; Colombo \& Burani, 2002; Holmes \& Ellis, 2006; Juhasz \& Rayner, 2006; Meschyan \& Hernandez, 2002; Mobaghan \& Ellis, 2002; Navarrete, Scaltritti, Mulatti, \& Peressotti, 2013; Pérez, 2007; Turner, Valentine, \& Ellis, 1998). However, some studies have contrasted either younger adults with older adults (Barry, Johnston, \& Wood, 2006; De Deyne \& Storms, 2007; Morrison, Hirsh, \& Duggan, 2003; Sirois, Kremin, \& Cohen, 2006) or adults suffering from impairments with control groups (Alzheimer's disease: Lambon Ralph \& Ehsan, 2006; Lymperopoulou, Barry, \& Sakka, 2006; cognitive impairments: Morrison et al., 2003; aphasia: Catling, South, \& Dent, 2013).

\section{Subjective and objective AoA}

Subjective AoA In the majority of AoA studies, subjective AoA ratings were obtained by asking adult native speakers to estimate when they had learned given words, by indicating either the exact age (in years) or an age range on a scale. This procedure has been used widely for both English and other languages, such as Chinese, Dutch, French, German, Greek, Icelandic, Italian, Japanese, Persian, Portuguese, Russian, Spanish, and Turkish (see Table 2 for studies on each language). Although there are concerns regarding the validity of such subjective ratings, in terms of adults' inability to remember the exact age of word learning (e.g., Morrison, Chappell, \& Ellis, 1997), many studies have found these estimates to be predictive of various processing variables in the different types of tasks listed above (a list of references is presented in Table 1). 
Table 1 Age-of-acquisition effects in different types of tasks in adults and children

\begin{tabular}{|c|c|c|c|}
\hline Task & Language & Children [age] & Adults \\
\hline \multirow[t]{8}{*}{ Picture naming } & Dutch & & Severens, Van Lommel, Ratinckx, and Hartsuiker (2005) \\
\hline & English & $\begin{array}{l}\text { Gerhand and Barry } \\
\text { (1999) [14-15 } \\
\text { years] }\end{array}$ & $\begin{array}{l}\text { Barry, Hirsh, Johnston, and Williams (2001); Barry et al. (2006); Barry et al. (1997); } \\
\text { Belke, Brysbaert, Meyer, and Ghyselinck (2005); Bogka et al. (2003); Brown and } \\
\text { Watson (1987); Carroll and White (1973b); Catling, South, and Dent (2013); } \\
\text { Garlock, Walley, and Metsala (2001); Holmes and Ellis (2006); Jorm (1991); } \\
\text { Kittredge, Dell, Verkuilen, and Schwartz (2008); Lachman, Shaffer, and Hennrikus } \\
\text { (1974); Lambon Ralph and Ehsan (2006); Lyons et al. (1978); Meschyan and } \\
\text { Hernandez (2002); Morrison, Ellis, and Quinlan (1992); Morrison, Hirsh, and } \\
\text { Duggan (2003); Walley and Metsala (1992) }\end{array}$ \\
\hline & French & & $\begin{array}{l}\text { Bonin, Chalard, Méot, and Fayol (2002); Bonin, Fayol, and Chalard (2001); Chalard } \\
\text { and Bonin (2006); Laganaro and Perret (2011) }\end{array}$ \\
\hline & Greek & & Bogka et al. (2003); Lymperopoulou, Barry, and Sakka (2006) \\
\hline & Italian & $\begin{array}{l}\text { D'Amico, Devescovi, } \\
\text { and Bates }(2001) \\
\text { [5-6 years }]\end{array}$ & $\begin{array}{l}\text { Bates, Burani, D'Amico, and Barca (2001); Colombo and Burani (2002); Navarrete, } \\
\text { Scaltritti, Mulatti, and Peressotti (2013) }\end{array}$ \\
\hline & Persian & & Bakhtiar et al. (2013) \\
\hline & Spanish & & Pérez (2007); Wilson, Cuetos, Davies, and Burani (2013) \\
\hline & Turkish & & Raman (2011) \\
\hline \multirow[t]{6}{*}{ Word naming } & Dutch & & Brysbaert (1996); Brysbaert, Lange, and Van Wijnendaele (2000a) \\
\hline & English & $\begin{array}{l}\text { Coltheart, Laxon, and } \\
\text { Keating }(1988) \\
{[9-10 \text { years }]}\end{array}$ & $\begin{array}{l}\text { Barry and Gerhand (2003); Barry et al. (2001); Brysbaert and Cortese (2011); Cortese } \\
\text { and Schock (2013); Meschyan and Hernandez (2002); Mobaghan and Ellis (2002) }\end{array}$ \\
\hline & French & & Bonin, Barry, Méot, and Chalard (2004) \\
\hline & Italian & & Bates et al. (2001); Wilson, Ellis, and Burani (2012) \\
\hline & Japanese & & Havelka and Tomita (2006) \\
\hline & Turkish & & Raman (2011) \\
\hline Object recognition & English & $\begin{array}{l}\text { Ellis and Morrison } \\
\text { (1998) [3-6 years] }\end{array}$ & \\
\hline \multirow[t]{2}{*}{ Word category decision } & Chinese & & Bai, Ma, Dunlap, and Chen (2013) \\
\hline & English & & Holmes and Ellis (2006) \\
\hline \multirow[t]{2}{*}{ Semantic classification } & Dutch & & Brysbaert, Van Wijnendaele, and De Deyne (2000) \\
\hline & English & & $\begin{array}{l}\text { Barry et al. (1997); Lambon Ralph and Ehsan (2006); Lyons et al. (1978); Moore, } \\
\text { Smith-Spark, and Valentine (2004); Morrison and Gibbons (2006) }\end{array}$ \\
\hline Associations & Dutch & & Brysbaert et al. (2000a, b); De Deyne and Storms (2008) \\
\hline \multirow[t]{5}{*}{ Lexical decision } & Dutch & & $\begin{array}{l}\text { Baumeister (1984); Brysbaert, Lange, and Van Wijnendaele (2000); De Deyne and } \\
\text { Storms (2007) }\end{array}$ \\
\hline & English & $\begin{array}{l}\text { Assink, van Well, and } \\
\text { Knuijt (2003) } \\
{[11-17 \text { years }]}\end{array}$ & $\begin{array}{l}\text { Assink et al. (2003); Barry et al. (2006); Baumeister (1984); Brysbaert and Cortese } \\
\text { (2011); Cortese and Schock (2013); Holmes, Fitch, and Ellis (2006); Stadthagen- } \\
\text { Gonzalez, Bowers, and Damian (2004); Turner, Valentine, and Ellis (1998) }\end{array}$ \\
\hline & French & & Bonin et al. (2001) \\
\hline & Italian & & Colombo and Burani (2002); Spataro, Longobardi, Saraulli, and Rossi-Arnaud (2013) \\
\hline & Spanish & & González-Nosti, Barbón, Rodríguez-Ferreiro, and Cuetos (2014); Wilson et al. (2013) \\
\hline Orthographic decision & Italian & & Adorni, Manfredi, and Proverbio (2013) \\
\hline Sentence reading & English & & Juhasz and Rayner (2006); Morrison, Hirsh, Chappell, and Ellis (2002) \\
\hline
\end{tabular}

Objective AoA Objective measurement of AoA has been based on spontaneous speech samples of children of various ages. Once the samples are transcribed and the words occurring in the transcriptions are counted by age groups, it is possible to estimate the AoA of the words present in the samples. The age at which a given word appears in the speech of the majority of children or reaches an arbitrarily set criterion of cumulative frequency is identified as its AoA. For instance, Piñeiro and Manzano (2000) defined the AoA of a word as the age range in which the word's cumulative frequency reaches $10 \%$ of its total frequency (in a given sample). They analyzed transcriptions of spontaneous speech of 200 children 11 to 49 months of age (divided into 11 age intervals of 2-4 months), and for each word they calculated its overall token frequency 
Table 2 Existing subjective and objective age-of-acquisition norms in different languages

\begin{tabular}{|c|c|c|}
\hline Language & Subjective Ratings & Objective Ratings \\
\hline Chinese & Liu et al. (2007) & Liu et al. (2011) \\
\hline Dutch $^{*}$ & $\begin{array}{l}\text { Brysbaert et al. (2014); De Deyne and Storms (2008); Ghyselinck et al. (2003); Ghyselinck } \\
\text { et al. (2000); Moors et al. (2013); Shao et al. (2014) }\end{array}$ & \\
\hline English $^{*}$ & $\begin{array}{l}\text { Auer and Bernstein (2008); Barry et al. (1997); Bird et al. (2001); Carroll and White (1973a, b); } \\
\text { Cortese and Khanna (2007, 2008); Gilhooly and Hay (1977); Gilhooly and Logie (1980); } \\
\text { Iyer et al. (2001); Johnston et al. (2010); Khanna and Cortese (2011); Kuperman et al. (2012); } \\
\text { Salmon et al. (2010); Schock et al. (2012); Snodgrass and Yuditsky (1996); Stadthagen- } \\
\text { Gonzalez and Davis (2006); Stration et al. (1975); Winters et al. (1978) }\end{array}$ & Morrison et al. (1997) \\
\hline French $^{*}$ & $\begin{array}{l}\text { Alario and Ferrand (1999); Bonin, Boyer, et al. (2004); Bonin et al. (2003); Bonin et al. (2008); } \\
\text { Ferrand et al. (2008); Sirois et al. (2006) }\end{array}$ & $\begin{array}{l}\text { Cannard and Kandel (2008); } \\
\text { Chalard et al. (2003) }\end{array}$ \\
\hline German $^{*}$ & Schröder et al. (2011) & \\
\hline Greek $^{*}$ & Dimitropoulou et al. (2009) & \\
\hline Icelandic ${ }^{*}$ & Pind et al. (2000) & Pind et al. (2000) \\
\hline Italian $^{*}$ & Barca et al. (2002); Colombo and Burani (2002); Della Rosa et al. (2010) & $\begin{array}{l}\text { Barbarotto et al. (2005); } \\
\text { Lotto et al. (2010) }\end{array}$ \\
\hline Japanese & Nishimoto et al. (2005); Nishimoto et al. (2012) & \\
\hline Norwegian & Lind et al. (2015) & \\
\hline Persian & Bakhtiar et al. (2013) & \\
\hline Portuguese & Cameirão and Vicente (2010); Marques et al. (2007) & \\
\hline Russian $^{*}$ & Akinina et al. (2014); Tsaparina et al. (2011) & Grigoriev and Oshhepkov (2013) \\
\hline Spanish $^{*}$ & $\begin{array}{l}\text { Alonso et al. (2015); Cuetos et al. (1999); Cuetos et al. (2012); Manoiloff et al. (2010); Moreno- } \\
\text { Martínez et al. (2014) }\end{array}$ & $\begin{array}{l}\text { Álvarez and Cuetos (2007); } \\
\text { Pérez and Navalon (2005) }\end{array}$ \\
\hline Turkish $^{*}$ & Raman et al. (2014) & \\
\hline
\end{tabular}

* Languages used in the present study

in the sample (total frequency). AoA was calculated only for words whose total frequency equaled at least 10 (298 word types). They assessed cumulative frequency by age intervals, and the lowest age interval in which a criterion of $10 \%$ of the total frequency for a given word was reached was assumed to be this word's AoA. They differentiated AoA from the first time uttered (FTU), explaining that the FTU indicates the age interval within which a specific word may appear for the first time, whereas AoA shows approximately the age at which the same word begins to receive a determined meaning in the active vocabulary of the child (Piñeiro \& Manzano, 2000). However, the AoA norms estimated on the basis of the spontaneous speech production of children may (1) not include all of the vocabulary utilized by children, (2) depend strongly on the context of data collection, and (3) be limited in that it does not include words comprehended but not yet produced by children.

Norms for the MacArthur-Bates Communicative Development Inventories (Fenson et al., 1993; Fenson et al., 2007) (henceforth, MB-CDI) also act as a source of information on the age at which children learn words. In the MB-CDI studies, parents of young children (from 8 up to 36 months of age, depending on the language) assess which of the words listed their children have comprehended and/or produced. On the basis of parental reports, it is possible to determine how many children in a given age range know the particular words. These indices allow one to establish the age at which the majority of children understand or say the items. The AoA ratings obtained by this procedure should be treated as quasi-objective, since they rely heavily on an indirect measurement of vocabulary knowledge: the parental report. Yet, MB$\mathrm{CDI}$ in itself has been validated by independent direct testing of child vocabulary and was found to be highly reliable (e.g., Dale, 1991; Dromi, Maital, Sagi, \& Bornstein, 2000; Heilmann, Ellis Weismer, Evans, \& Hollar, 2005; Thai, O'Hanlon, Clemmons, \& Fralin, 1999; Thordardottir \& Ellis Weismer, 1996).

Another method to assess objective AoA is elicitation of children's verbal production using picture naming (Morrison et al., 1997). In this procedure, participants are shown a set of pictures of common objects or activities that they have to name. To obtain the AoA, participants are classified by age, and the AoA of a given word is considered to be the mean age of the group in which the picture is correctly named with relatively high frequency (usually, equal to or greater than $75 \%$ ). This method has been used in several studies focusing on a total of seven languages (see Table 2 for the detailed references): Chinese, English, French, Icelandic, Italian, Russian, and Spanish. Researchers examined different age ranges from 2 to 15 years, usually 2 to 11 years. Objective 
AoA ratings have also been calculated on the basis of word definitions provided by participants 5 to 21 years of age (Gilhooly \& Gilhooly, 1980).

Although some researchers prefer to use objective ratings (e.g., Morrison et al., 1997), results obtained by the two methods have proven to be highly correlated, at least for some languages. Carroll and White (1973b) correlated subjective AoA ratings collected from 62 adult speakers of English with objective measures of AoA (ratings of how often different age groups use some words in reading and writing) and obtained a coefficient of .85. Gilhooly and Gilhooly (1980) found a correlation of .93 between the ratings of AoA provided by 70 psychology students and the standardized Crichton/Mill Hill vocabulary norms for children 5 to 11 years of age (Gilhooly \& Gilhooly, 1980). Additionally, they reported a correlation of .84 between ratings and accuracy in a word-defining task in which children 5 to 13 years of age were asked to describe the meanings of words. Similarly, a correlation $(r=.76)$ between subjective AoA and objective AoA (defined as the age at which $75 \%$ of children in a given age group knew the name for an object in a picture-naming task) was found by Morrison, Chappell, and Ellis (1997). Other studies (De Moor, Ghyselinck, \& Brysbaert, 2000; Jorm, 1991; Lyons, Teer, \& Rubenstein, 1978) have also provided evidence for the validity of subjective AoA ratings as a psycholinguistic variable.

\section{Methodological aspects of AoA studies}

Scales used in AoA studies In the majority of subjective AoA studies, one of four types of scales have been used: an 11-point scale based on equivalent age, a 9-point scale utilized for the first time by Carroll and White (1973a), a 7-point scale introduced by Gilhooly and Logie (1980), or a 5-point scale. These scales were mostly used as variants of Likert-type scales (see the descriptions in Table 3) in studies in which norms for other psycholinguistic variables, such as familiarity, imageability, concreteness, meaningfulness, visual complexity, name and image agreement, and subjective frequency were collected in addition to AoA (e.g., Akinina et al., 2014; Alario \& Ferrand, 1999; Bakhtiar, Nilipour, \& Weekes, 2013; Barca, Burani, \& Arduino, 2002; Bird, Franklin, \& Howard, 2001; Bonin, Peereman, Malardier, Méot, \& Chalard, 2003; Cuetos, Ellis, \& Alvarez, 1999; Della Rosa, Catricalà, Vigliocco, \& Cappa, 2010; Dimitropoulou, Duñabeitia, Blitsas, \& Carreiras, 2009; Ferrand et al., 2008; Gilhooly \& Logie, 1980; Liu, Hao, Li, \& Shu, 2011; Liu, Shu, \& Li, 2007; Manoiloff, Artstein, Canavoso, Fernández, \& Segui, 2010; Moreno-Martínez, Montoro, \& Rodríguez-Rojo, 2014; Nishimoto, Miyawaki, Ueda, Une, \& Takahashi, 2005; Pind, Jónsdóttir, Gissurardóttir, \& Jónsson, 2000; Raman, Raman, \& Mertan, 2014; Salmon, McMullen, \& Filliter, 2010; Shao, Roelofs, \&
Table 3 Most popular scales used in the studies on subjective age of acquisition

\begin{tabular}{|c|c|c|}
\hline Scale & Description & Examples of Studies \\
\hline 5-point & $\begin{array}{l}1=3 \text { years or earlier, } 2=4 \text { to } \\
6 \text { years, } 3=7 \text { to } 9 \text { years, } 4 \\
=10 \text { to } 12 \text { years, } 5=13 \\
\text { years or later }\end{array}$ & $\begin{array}{l}\text { Akinina et al. (2014); Alario } \\
\text { and Ferrand (1999); } \\
\text { Bonin, Boyer, et al. } \\
\text { (2004); Bonin et al. } \\
\text { (2003); Dimitropoulou } \\
\text { et al. (2009); Manoiloff } \\
\text { et al. (2010); Tsaparina } \\
\text { et al. (2011) }\end{array}$ \\
\hline 7-point & $\begin{array}{c}1=2 \text { years or earlier, } 2=3 \text { or } \\
4 \text { years, } 3=5 \text { or } 6 \text { years, } 4 \\
=7 \text { or } 8 \text { years, } 5=9 \text { or } 10 \\
\text { years, } 6=11 \text { or } 12 \text { years, } \\
7=13 \text { years or later }\end{array}$ & $\begin{array}{l}\text { Barca et al. (2002); Barry } \\
\text { et al. (1997); Bird et al. } \\
\text { (2001); Bonin et al. } \\
\text { (2008); Cortese and } \\
\text { Khanna (2007, 2008); Liu } \\
\text { et al. (2011); Moreno- } \\
\text { Martínez et al. (2014); } \\
\text { Pind et al. (2000); Salmon } \\
\text { et al. (2010); Schock et al. } \\
\text { (2012); Schröder et al. } \\
\text { (2011); Sirois et al. } \\
\text { (2006); Snodgrass and } \\
\text { Yuditsky (1996) }\end{array}$ \\
\hline 9-point & $\begin{array}{c}1=2 \text { years or earlier, } 2=3 \\
\text { years, } 3=4 \text { years, } 4=5 \\
\text { years, } 5=6 \text { years, } 6=7 \text { or } \\
8 \text { years, } 7=9 \text { or } 10 \text { years, } \\
8=11 \text { or } 12 \text { years, } 9=13 \\
\text { years or later }\end{array}$ & $\begin{array}{l}\text { Cameirão and Vicente } \\
\text { (2010); Carrol and White } \\
\text { (1973a) Iyer et al. (2001); } \\
\text { Lyons et al. (1978); } \\
\text { Mobaghan and Ellis } \\
\text { (2002); Nishimoto et al. } \\
\text { (2005); Nishimoto et al. } \\
\text { (2012); Shao et al. (2014); } \\
\text { Stration et al. (1975); } \\
\text { Vinson et al. (2008); } \\
\text { Walley and Metsala } \\
\text { (1992); Winters et al. } \\
\text { (1978) }\end{array}$ \\
\hline 11-point & $\begin{array}{l}\text { based on equivalent age, } 1= \\
\text { earlier than } 2 \text { years, } 2=2 \\
\text { years, } 3=3 \text { years, } \ldots, 10 \\
=10 \text { years, } 11=11 \text { years } \\
\text { or later }\end{array}$ & $\begin{array}{l}\text { Alonso, Fernandez, and Díez } \\
\text { (2015); Bakhtiar, } \\
\text { Nilipour, and Weekes } \\
\text { (2013) }\end{array}$ \\
\hline Continuous & $\begin{array}{l}\text { years given in exact } \\
\text { numbers: } 1=1 \text { year, } 2=2 \\
\text { years, } \ldots, 18=18 \text { years, } \\
\text { etc. }\end{array}$ & $\begin{array}{l}\text { Brysbaert et al. (2014); } \\
\text { Cuetos, Samartino, and } \\
\text { Ellis (2012); De Deyne } \\
\text { and Storms (2007); Della } \\
\text { Rosa et al. (2010); } \\
\text { Ferrand et al. (2008); } \\
\text { Ghyselinck, Custers, and } \\
\text { Brysbaert (2003); } \\
\text { Gilhooly and Logie } \\
\text { (1980); Kuperman, } \\
\text { Stadthagen-Gonzalez, and } \\
\text { Brysbaert (2012); } \\
\text { Stadthagen-Gonzalez and } \\
\text { Davis (2006) }\end{array}$ \\
\hline
\end{tabular}

Meyer, 2014; Sirois et al., 2006; Snodgrass \& Yuditsky, 1996; Stration, Jacobus, \& Brinley, 1975; Tsaparina, Bonin, \& Méot, 2011; Vinson, Cormier, Denmark, Schembri, \& Vigliocco, 2008). Other scales have sometimes been modified according 
to the objectives of the specific study. For example, Auer and Bernstein (2008) used an 11-point scale with the last point set at age 21 , because they assumed that many of their stimuli would be assessed as being acquired after the age of 13 years.

Other studies (e.g., Cuetos, Samartino, \& Ellis, 2012; De Deyne \& Storms, 2007; Della Rosa et al., 2010; Ferrand et al., 2008; Kuperman, Stadthagen-Gonzalez, \& Brysbaert, 2012; Stadthagen-Gonzalez \& Davis, 2006) have not used an explicit scale; rather, participants were asked to provide their subjective AoA directly in years - for example, to type the number " 3 " if they thought they had learned a given word at the age of 3 years, and " $N$ " or " $\mathrm{X}$ " if they did not know the word at the time of data collection (Ferrand et al., 2008; Kuperman et al., 2012). Ferrand at al. argued that participants find the scaleless instructions easier to follow. Moreover, this kind of measure returns more precise information about the AoA of particular words.

\section{Target/experimental question in subjective AoA studies} Most AoA studies discuss the exact form of the target question used to elicit the AoA ratings in far less detail than they discuss the scale used. A review of 54 publications revealed that the majority of the subjective AoA studies did not state the exact form of the question at all (Akinina et al., 2014; Alario \& Ferrand, 1999; Alonso, Fernandez, \& Díez, 2015; Bakhtiar et al., 2013; Barry et al., 2006; Bird et al., 2001; Bonin, Boyer, Méot, Fayol, \& Droit, 2004b; Bonin et al., 2003; Bonin, Perret, Méot, Ferrand, \& Mermillod, 2008; Cameirão \& Vicente, 2010; Colombo \& Burani, 2002; Cuetos et al., 1999; Cuetos et al., 2012; De Deyne \& Storms, 2007; Della Rosa et al., 2010; Dimitropoulou et al., 2009; Johnston, Dent, Humphreys, \& Barry, 2010; Lyons et al., 1978; Manoiloff et al., 2010; Marques, Fonseca, Morais, \& Pinto, 2007; Moors et al., 2013; Moreno-Martínez et al., 2014; Nishimoto et al., 2005; Nishimoto, Ueda, Miyawaki, Une, \& Takahashi, 2012; Raman et al., 2014; Schock, Cortese, Khanna, \& Toppi, 2012; Schröder, Gemballa, Ruppin, \& Wartenburger, 2011; Sirois et al., 2006; Stration et al., 1975; Tsaparina et al., 2011; Vinson et al., 2008; Walley \& Metsala, 1992; Winters, Winter, \& Burger, 1978). In the remaining articles, the wording "When do you think you learned this word?" is most frequently used (e.g., Auer \& Bernstein, 2008; Barca et al., 2002). Some authors have reported the definition of word learning used in their studies (Kuperman et al., 2012; Moors et al., 2013; Shao et al., 2014; Stadthagen-Gonzalez \& Davis, 2006), explaining that the AoA of a word is the age at which participants would have understood that word if somebody had used it in front of them, even if they did not themselves use, read, or write it at the time.

All studies have so far focused on participants' own experience of word learning. This method may return ratings that overestimate the AoA of some relatively new words (e.g., $a$ computer). So far, no study has used a question concerning adult participants' opinions on the word learning of today's children: "When do children learn this word?" To avoid task discrepancy in the ways that estimations were elicited, we followed the most frequent pattern of target questions ("When did you learn this word?") in the present study. However, because we expected that the exact form of the target question might reveal differences in the estimations, we conducted a one-language control study in which a question on current children's experience was used.

Word classes in AoA studies The vast majority of both objective and subjective AoA ratings have been gathered for nouns only (e.g., Alario \& Ferrand, 1999; Álvarez \& Cuetos, 2007; Bakhtiar et al., 2013; Barbarotto, Laiacona, \& Capitani, 2005; Barca, Burani, \& Arduino, 2002; Barry, Morrison, \& Ellis, 1997; Bonin et al., 2003; Cannard \& Kandel, 2008; Carroll \& White, 1973a, 1973b; Chalard, Bonin, Méot, Boyer, \& Fayol, 2003; Cortese \& Khanna, 2007, 2008; Cuetos et al., 1999; Cuetos et al., 2012; De Deyne \& Storms, 2007; Della Rosa et al., 2010; Dimitropoulou et al., 2009; Ghyselinck, De Moor, \& Brysbaert, 2000; Grigoriev \& Oshhepkov, 2013; Iyer, Saccuman, Bates, \& Wulfeck, 2001; Johnston et al., 2010; Liu et al., 2011; Lotto, Surian, \& Job, 2010; Lyons et al., 1978; Manoiloff et al., 2010; Marques et al., 2007; MorenoMartínez et al., 2014; Morrison et al., 1997; Nishimoto et al., 2005; Nishimoto et al., 2012; Pérez \& Navalon, 2005; Pind et al., 2000; Raman et al., 2014; Salmon et al., 2010; Schröder et al., 2011; Sirois et al., 2006; Snodgrass \& Yuditsky, 1996; Stration et al., 1975; Tsaparina et al., 2011; Winters et al., 1978). Other word classes have been included in only 17 studies (Akinina et al., 2014; Alonso et al., 2015; Bird et al., 2001; Bonin, Boyer, et al., 2004; Brysbaert, Stevens, De Deyne, Voorspoels, \& Storms, 2014; Cameirão \& Vicente, 2010; Colombo \& Burani, 2002; Ferrand et al., 2008; Ghyselinck, Custers, \& Brysbaert, 2003; Gilhooly \& Hay, 1977; Gilhooly \& Logie, 1980; Kuperman et al., 2012; Moors et al., 2013; Piñeiro \& Manzano, 2000; Schock et al., 2012; Shao et al., 2014; Stadthagen-Gonzalez \& Davis, 2006). However, in most of these studies, even if verbs or other word classes were included, nouns were still the dominating category (in terms of the number of items). Only two megastudies have included all possible word classes, comprising as many as 30,000 words: one for English (Kuperman et al., 2012) and one for Dutch (Brysbaert et al., 2014). The present study is the first that has aimed to make available AoA ratings for a balanced number of nouns and verbs in a wide range of languages, thereby making it possible to compare AoAs within both word classes cross-linguistically.

Word set size in AoA studies The sizes of the word sets for which AoA ratings were collected have also differed between studies, from 80 (Barbarotto et al., 2005) to as many as 30,000 
(Brysbaert et al., 2014; Kuperman et al., 2012), but mostly between 100 and 850 words (for $72 \%$ of the 64 studies reviewed). In some cases, the size of the data set depended on the number of pictures accompanying the study (e.g., the 260 pictures of the Snodgrass \& Vanderwart, 1980, picture set have been used in Barry et al., 1997; Dimitropoulou et al., 2009; Pind et al., 2000; Raman et al., 2014; Snodgrass \& Yuditsky, 1996; Tsaparina et al., 2011). In the present study, we used a limited set of 299 words, which had previously been used in a cross-linguistic naming study and had been shown to have the same meanings in 34 languages (Haman, Łuniewska, \& Pomiechowska, 2015; Haman, SzewczykMieszkowska, et al., in preaparation).

AoA across languages In the studies mentioned above, subjective AoA was estimated in 14 different languages, mostly Indo-European. For Germanic languages, data have been gathered for Dutch, English, German, Icelandic, and Norwegian. For Romance languages, data are available for French, Italian, Portuguese, and Spanish. Other IndoEuropean languages studied are Greek, Persian, and Russian. The only languages outside the Indo-European family so far that have AoA ratings are Chinese, Turkish, and Japanese (see Table 2).

However, no fully comparable ratings of objective or subjective AoA have been obtained with the very same procedure across languages. Some of the AoA studies are based on the same set of words linked to the Snodgrass and Vanderwart (1980) object pictures (e.g., Barry et al., 1997 [English]; Pind et al., 2000 [Icelandic]; Snodgrass \& Yuditsky, 1996 [English]; Tsaparina et al., 2011 [Russian]). However, although the same set of words was rated in these studies, the data collection procedure varied. In the studies by Snodgrass and Yuditsky (1996) and Pind et al. (2000), participants were asked to rate when they thought they had learned the words that they saw accompanied by the Snodgrass and Vanderwart pictures (black-and-white version); in the study by Tsaparina et al. (2011), participants instead saw a colorized version of the pictures (Rossion \& Pourtois, 2004), whereas in the Barry et al. (1997) study, participants saw only written words. Also, different measurement scales were used in the studies: Tsaparina et al. used a 5-point scale, whereas a 7-point scale was used by Barry et al. (1997) and Pind et al., and a 9-point scale was used in the study by Snodgrass and Yuditsky. Different procedures and measurement scales make the results obtained in these studies hard to compare cross-linguistically, since the ratings may depend on both the exact stimulus form and the type of scale used.

\section{The present study}

The motivations for our study were both practical and theoretical. First, because of the existence of the AoA effect (viz. the observation that words acquired earlier in life are processed faster than words learned later, as described above), we planned to use AoA ratings as a factor for the construction of cross-linguistic lexical tasks (Haman, Łuniewska, \& Pomiechowska, 2015). Second, by performing the AoA study in a uniform way across such a wide range of languages, we aimed to obtain new evidence for the classic claim of a universal pattern in early meaning acquisition among languages (Clark, 1979, 1995, 2001). Clark argued that children's early words in various languages fall into a small number of the same semantic categories like: people, food, body parts, clothing, animals, vehicles, toys, household objects, routines, and activities or states (Clark, 2009, p. 76). This argument was based on a cross-linguistic speech diary analysis and comparison of its results with the MB-CDI's list of the first 50 words in American English (Fenson, Reznick, Bates, Thal, \& Pethick, 1994). Clark further argued that in the course of lexical development over the second and third years of life, children elaborate the semantic domains by adding new words into and subdividing the domains (Clark, 1995). Although the present study is not limited to children's early words, about $95 \%$ of the words used in the study fall into the categories indicated by Clark. Thus, we assumed that the universality of early semantic categories and the process of their elaboration in child language might be also reflected in the AoA order of similar words across languages.

Therefore, we collected data on subjective AoA ratings in 25 languages to assess how stable the ratings can be cross-linguistically and to check their validity by comparing them between language pairs and against previous AoA scores. We expected the ratings to be correlated between language pairs, and we predicted that the more similar two languages or cultures are, the higher the correlation coefficients would be.

Additionally, we analyzed how the demographic characteristics of participants (their gender, age, education, being a parent or not, and language status) influenced their AoA estimations. We expected that the AoA of the majority of the words would not depend on participants' age. Some words might have been acquired earlier by younger and later by older participants, according to the availability of the objects or actions depicted by the words when the participants were growing up. Specifically, we predicted that several words labeling new artifacts (e.g., a computer) and more recently introduced activities (e.g., to surf) would be rated as being acquired relatively earlier in life by the younger group and later by the older group. We did not expect the AoA ratings to depend on participants' education level and gender. However, we did assume that being a parent (having or recently having had small children who were acquiring language) might influence adults' ability to assess when they themselves had learned the words - that is, their ratings might be affected by fresh experience with their own children. 
Because bilingual children typically have smaller vocabulary sizes than their monolingual peers (if measured in one language only), they might acquire some words later than monolinguals (Bialystok, Luk, Peets, \& Yang, 2010). We predicted that adults who reported that they spoke more than one language at a level similar to that of native speakers and who began their second language learning in childhood would estimate that they learned words later than monolinguals.

In the present study, we also assessed whether two different target questions, "When did you learn this word?" versus "When do children learn this word?," would affect ratings for words. As was stated above, children nowadays might learn words for recently introduced objects and activities at a young age, whereas older participants might have been more advanced in age at the time of introduction of the said objects and activities.

Besides comparisons with previous AoA data, we adopted another method of validity estimation, following the study by Lind, Simonsen, Hansen, Holm, and Mevik (2015). We compared our data to the available norms for MB-CDIs in nine languages: American English (Dale \& Fenson, 1996), Croatian (Kuvac et al., 2009), Danish (Bleses et al., 2008), German (Szagun, Stumper, \& Schramm, 2009), Italian (Camaioni, Caselli, Longobardi, \& Volterra, 1991), Mexican Spanish (Dale \& Fenson, 1996), Russian (Eliseeva \& Vershinina, 2009), Swedish (Eriksson \& Berglund, 1999), and Turkish (Aksu-Koç et al., 2009).

For a given pair of data (MB-CDI vs. AoA), the percentage of children who know a given word at a certain age (obtained from the MB-CDI norms) was contrasted with the mean AoA of the same word (obtained in the present AoA study). The higher the proportion of children who were reported to know the word, the lower we expected the AoA for a given word to be. Thus, we expected negative correlations between the MBCDI norms and the AoA ratings.

Although MB-CDIs are now available in 61 languages (Dale \& Penfold, 2011), normative data for single words have so far only been published for six out of the 25 languages included in our sample (Jørgensen, Dale, Bleses, \& Fenson, 2009). Thus, in the case of these six languages (Danish, German, Italian, Russian, Swedish, and Turkish), we were able to compare our AoA ratings with the MB-CDI norms in exactly the same language. MB-CDI norms were also available for another three languages that are very close to the ones from our sample. Thus, we compared the AoA ratings in Serbian, Spanish, and both British and South African English to the available MB-CDI norms for Croatian, Mexican Spanish, and American English, respectively. The available MB-CDI norms were either downloaded from the Wordbank (http://wordbank.stanford.edu/; in the case of all Turkish data and the Croatian Words \& Sentences part) or the CLEX website (www.cdi-clex.org/; in the case of the remaining data).
There are two versions of the MB-CDI-namely Words \& Gestures (adapted mostly for toddlers 8-18 months of age and assessing both word production and comprehension) and Words \& Sentences (designed for the assessment of word production only in older children, mostly 16 to 36 months of age ). We used both MB-CDI versions for Danish, Russian, Turkish, American English, Serbian, and Mexican Spanish. Thus, for these languages we analyzed norms obtained from children 8 to 36 months of age. Swedish norms were available only for the Words \& Gestures part, and hence only for children 8 to 16 months of age, whereas the German and Italian norms were available only for children 18 to 36 months of age in the Words \& Sentences part.

For seven of the nine languages used in the comparisons, the MB-CDI norms included ratings for both receptive and expressive vocabulary. Although in our AoA study participants were asked to estimate when they could understand the word, which explicitly taps receptive vocabulary knowledge, we contrasted our results with both receptive and expressive norms from the MB-CDIs. However, it was expected that the receptive MB-CDI norms would have a stronger relation to our AoA results than would the expressive MB-CDI norms.

\section{Method}

\section{Participants}

The participants were 827 adults, a minimum of 20 per language (total range: 20 to $124, M=31, S D=21$; see Table 4). The data from 31 participants were excluded from the analyses for reasons described in detail in the Data Processing section below. The participants whose data were included in subsequent analyses were 622 females (78\%) and 174 males, 18 to 80 years of age $(M=30.8$, $S D=12.3)$. Participants were recruited in a variety of ways: mostly via academic communication (lecturers informing students about the study) or by social media (e.g., Facebook), but also through neighborhood networks and chain-referral sampling. Participants received certificates of participation on request, and those for some languages also received course credits. All participants reported their education level, occupation, country of residence, native language, numbers of spoken and used languages, and the number and age of their children.

Twenty-three participants recruited in the ways described above took part in the control study, in which the target question was replaced with the one concerning word knowledge in children. They were all Polish native speakers (17 female, six male; age: $M=38.6, S D=10.7$ ). None of these participants participated in the study where the main question ("When did you learn the word?") was used. 
Table 4 Characteristics of the participants included in the analysis, per language

\begin{tabular}{|c|c|c|c|c|c|c|}
\hline & \multirow[t]{2}{*}{ Language } & \multirow[t]{2}{*}{$N$} & \multicolumn{2}{|l|}{ Age } & \multicolumn{2}{|c|}{ Females } \\
\hline & & & $M$ & $S D$ & $N$ & Percent \\
\hline 1 & Afrikaans & 37 & 35.89 & 15.00 & 18 & $49 \%$ \\
\hline 2 & Catalan & 20 & 34.65 & 18.35 & 11 & $55 \%$ \\
\hline 3 & Danish & 23 & 32.22 & 11.20 & 23 & $100 \%$ \\
\hline 4 & Dutch & 22 & 31.68 & 11.69 & 15 & $68 \%$ \\
\hline 5 & English (British) & 124 & 21.26 & 4.93 & 96 & $77 \%$ \\
\hline 6 & English (South African) & 42 & 30.48 & 14.76 & 33 & $79 \%$ \\
\hline 7 & Finnish & 24 & 32.79 & 9.70 & 23 & $96 \%$ \\
\hline 8 & German & 21 & 30.00 & 10.48 & 15 & $71 \%$ \\
\hline 9 & Greek & 34 & 26.24 & 8.68 & 28 & $82 \%$ \\
\hline 10 & Hebrew & 21 & 31.81 & 10.20 & 18 & $86 \%$ \\
\hline 11 & Hungarian & 21 & 46.86 & 14.36 & 17 & $81 \%$ \\
\hline 12 & Icelandic & 23 & 42.09 & 13.02 & 20 & $87 \%$ \\
\hline 13 & Irish & 20 & 36.15 & 13.54 & 14 & $70 \%$ \\
\hline 14 & isiXhosa & 27 & 32.00 & 16.84 & 18 & $67 \%$ \\
\hline 15 & Italian & 25 & 23.04 & 7.31 & 22 & $88 \%$ \\
\hline 16 & Lithuanian & 28 & 30.82 & 9.17 & 26 & $93 \%$ \\
\hline 17 & Luxembourgian & 22 & 38.27 & 12.59 & 16 & $73 \%$ \\
\hline 18 & Maltese & 21 & 32.95 & 13.26 & 18 & $86 \%$ \\
\hline \multirow[t]{2}{*}{19} & Polish & 32 & 24.94 & 7.28 & 25 & $78 \%$ \\
\hline & Polish: revised question & 23 & 38.61 & 10.65 & 23 & $74 \%$ \\
\hline 20 & Russian & 36 & 35.39 & 10.30 & 31 & $86 \%$ \\
\hline 21 & Serbian & 33 & 19.64 & 0.99 & 26 & $79 \%$ \\
\hline 22 & Slovak & 33 & 25.67 & 9.77 & 30 & $91 \%$ \\
\hline 23 & Spanish & 22 & 27.36 & 7.54 & 16 & $73 \%$ \\
\hline 24 & Swedish & 23 & 37.65 & 15.08 & 15 & $65 \%$ \\
\hline \multirow[t]{2}{*}{25} & Turkish & 39 & 29.56 & 4.33 & 31 & $79 \%$ \\
\hline & TOTAL & 796 & 30.08 & 12.35 & 622 & $78 \%$ \\
\hline
\end{tabular}

\section{Stimuli}

The same sets of 158 nouns and 141 verbs (total of 299 words) were used in each language. The words had been selected in a previous online picture-naming study (Haman, Łuniewska, \& Pomiechowska, 2015; Haman, SzewczykMieszkowska, et al., in preaparation) conducted in 34 languages, including each of the languages considered in the present study. Since the words were selected on the basis of the picture-naming study, they labeled imageable objects and actions.

In the naming study, 93 competent raters (native speakers of 34 different languages) named 1,024 pictures (507 object and 517 action pictures). Each participant first assessed whether the pictures easily evoked a single word in his or her native language. The rater then provided words in her or his native languages for the objects and actions presented in the pictures, and then typed the English equivalents of these words. Additionally, for purposes not linked to the present study, participants provided ratings of the picture style. All pictures in the naming study had previously been used in various psycholinguistic studies (with both children of various ages and with adults) in a total of 15 languages. They were gathered from eight sources, representing different picture styles (line drawings, photos, color drawings, etc.).

The data from 76 raters who completed more than $25 \%$ of the procedure were used to select the most widely shared meanings. Haman and colleagues (Haman, Łuniewska, \& Pomiechowska, 2015; Haman, SzewczykMieszkowska, et al., in preaparation) selected words on the basis of the highest agreement of naming (computed on the English translations). The pictures illustrating the selected words had thus been assessed by the majority of the judges across languages as easily evoking one word or several words similar in meaning. The words for objects and actions were selected separately. This procedure, together with the AoA ratings, was initially designed as a basis for the construction of the LITMUS CrossLinguistic Lexical Tasks for the assessment of word knowledge in bilingual and multilingual children (see Haman, Łuniewska, \& Pomiechowska, 2015).

\section{5 language versions of the online procedure}

Lists of target words for each language were obtained as described above. In each language, the list of target words consisted of the labels provided by native speakers of this language during the naming study (Haman, Łuniewska, \& Pomiechowska, 2015; Haman, SzewczykMieszkowska, et al., in preaparation).

Instructions for the present study and all other information were first prepared in English. However, in order to avoid inconsistencies, collaborators speaking all languages involved were consulted at the stage of preparing the English version, and again while the target language versions were being prepared. Thus, adaptations of the procedure and the instructions for languages other than English were not mere translations of the English version; rather, they were pre-prepared during the first stage of study design. After preparing the model English version, all materials (the website, instructions, examples, etc.) were translated into each of the languages involved by native speakers who were also researchers (linguists or psycholinguists, mostly coauthors of the present article).

\section{Procedure}

The procedure was available online via a website designed exclusively for the purposes of the study (www.wordspsych.org). The website was made available in all 25 languages, so participants could use their native language exclusively while using the website. After entering the website, participants were instructed to download a file and open it in Microsoft Excel (or Open Office). The file contained four sheets. The first sheet presented basic information about 
the study and the instructions, and the second sheet contained questions on the demographics of the participants. The lists of nouns and verbs were presented on the third and fourth sheets, respectively. All of the instructions, questions, and words were presented in the mother tongue of the participants.

Participants were asked to decide at what age they had learned the words presented in the two sheets. The instruction was: "For each word please estimate the age (in years) at which you think you learned this word; that is, the age at which you would have understood that word if somebody had used it in front of you, even if you did not use, read or write it at the time." The exact form of the question was: "When did you learn the word?" Participants were asked to type a number from 1 (if they thought they had learned the word when they were one year old) to 18 (if they thought they had learned the word when they were 18 or older). They were encouraged to guess the age if they were not sure and not to spend too much time on any single word. If they did not know the word, they were asked to enter " $X$ " in the box. Both the instruction and the target question used in the present study closely matched those used in Kuperman, StadthagenGonzalez, and Brysbaert (2012), who in turn followed the instructions proposed by Stadthagen-Gonzalez and Davis (2006). Although many studies have used Likert scales rather than a continuous scale (from 1 to 18 or up to the participants' current age), we decided to use the latter one, following the remark of Kuperman et al. (2012) that the "[Likert-like scale] artificially restricts the response range and is also more difficult for participants to use" (p. 980). Also, Ghyselinck et al. (2003) stated that using a continuous scale makes the instructions given to participants as simple as possible.

To ensure that the participants understood the instructions, we provided four examples of both nouns and verbs acquired early and later in life. The examples were presented in a table that looked similar to the one filled out by the participants. Explanatory comments were added to the table (e.g., "Someone estimates that $\mathrm{s} / \mathrm{he}$ learned the word 'to ask' at the age of 3 years.").

The words on both the noun and the verb list were presented in a random order, generated individually for each participant during the file downloading. On the Nouns and Verbs sheets, below the list of words, a short thank-you note was presented, together with a reminder of the other sheet ("Thank you for filling in the table for nouns. Have you filled in the table for verbs as well?"). Each participant was given the full list of all 299 words. Task duration was about half an hour. After filling in the file, participants were asked to upload it via the website or to send it as an e-mail attachment to the address reserved for the purposes of the study.

For two out of the 25 languages, Hebrew and Luxembourgish, a paper-and-pencil version of the procedure was applied. In these two languages, the files were downloaded from the website by an experimenter, then printed and distributed among the participants. The instructions and organization of the sheets were identical to those aspects in the online procedure. The only reason for running the study offline for these two languages was difficulty with recruitment for online participation.

In the control study that addressed whether the question form affected the ratings, the procedure was the same as that described above. The only modified factors were the target question form ("When do children learn this word?" instead of "When did you learn the word?") and the descriptions of the examples ("Someone estimates that children learn the word 'to ask' at the age of 3 years."). The control study was run only in Polish in an across-subjects design. Participants of the control study did not participate in the main study, because this could have affected the Polish ratings in both designs.

\section{Data processing}

In the first step of data processing, we excluded 1ådata from any respondent who did not follow the procedure of ratings collection. Data from 16 respondents were excluded because the participants reported that they were not native speakers of the language in which they completed the survey. Additionally, we removed the data from nine respondents who did not provide demographic information, and from six who assessed less than $50 \%$ of the 299 words. Altogether, the data of 31 respondents $(3.8 \%)$ were removed from the database. Most of the remaining participants (84\%) assessed more than $95 \%$ of the the words. Only $2 \%$ of the participants provided estimations for less than $75 \%$ of the words. Participants who did not provide data for all items skipped some of the words in the file by leaving those lines blank. The blank lines were located in various parts of the files and were equally distributed across the items.

The second step aimed at removing all outliers from further analyses. We defined outliers as disproportionally high or low values for both the word and the participant in a given language. We excluded ratings meeting both of the following two criteria: (1) being three $S D$ s higher (or lower) than the mean for that word in a given language, and (2) being three $S D \mathrm{~s}$ higher (or lower) than the average estimation provided by a given participant inside a word class. Thus, to be an outlier, a single estimation of AoA of a particular word had to be both very late in comparison to other words learned by that participant and very late in comparison with the average AoA of that word in the same language. In this step, we removed 137 of the 125,879 ratings for nouns, and 110 of the 113,174 ratings for verbs (both about $1 \%$ ).

Although the instruction allowed participants to type " $\mathrm{X}$ " if they did not know a given word, there were no "X" answers. Thus, we did not include this type of response in the analysis. 


\section{Results}

\section{Descriptive results}

The ratings obtained for each of the 25 languages are presented in the supplemental materials. All of the words in the set were reported to be acquired between 1 and 12 years of age, and $98 \%$ of the words were assessed as being known to children younger than 7 years.

\section{Cross-linguistic comparison}

The AoA ratings in all languages were significantly correlated (Spearman's rho, adjusted for split-half reliabilities, ranged from .60 to .96; Table 5). The highest correlations were obtained for Polish and Slovak (adjusted $r_{\mathrm{S}}=.96$ ), Maltese and
Greek (adjusted $r_{\mathrm{S}}=.93$ ), and British and South African English (adjusted $r_{\mathrm{S}}=.91$ ). The adjusted coefficients were the lowest for Hungarian correlated with Italian (adjusted $r_{\mathrm{S}}$ $=.62$ ), Irish (adjusted $r_{\mathrm{S}}=.64$ ), and Hebrew (adjusted $r_{\mathrm{S}}=$ $.65)$; see Fig. 1.

Although the orders of word acquisition were similar across all of the languages studied, we found significant differences in the raw ratings of words between languages (see Fig. 2). Most of the words from our list were acquired between 2 and 8 years old, and the vast majority of them are reported to have be learned between 3 and 5 years. However, there are three evident exceptions among the languages: (1) Finnish, in which words were reported to be acquired earlier than in the other languages, and the majority of the words were acquired by the age of 4 years, and (2) Maltese and isiXhosa, in which words were reported to be acquired relatively later.

Table 5 Matrix of adjusted correlations of all languages with split-half reliabilities per language

\begin{tabular}{|c|c|c|c|c|c|c|c|c|c|c|c|c|c|c|c|c|c|c|c|c|c|c|c|c|c|}
\hline $\begin{array}{l}\text { Split-Half } \\
\text { Reliability }\end{array}$ & & $\mathrm{CA}$ & $\mathrm{DA}$ & NL & $\begin{array}{l}\mathrm{EN} \\
\mathrm{BR}\end{array}$ & $\begin{array}{l}\text { EN } \\
\text { SA }\end{array}$ & FI & $\mathrm{DE}$ & EL & $\mathrm{HE}$ & $\mathrm{HU}$ & IS & GA & $\mathrm{XH}$ & IT & LT & LB & MT & PL & RU & SR & SK & ES & SV & TR \\
\hline .91 & Africaan (AF) & .85 & .79 & .85 & .82 & .89 & .80 & .85 & .81 & .78 & .72 & .76 & .80 & .86 & .78 & .75 & .84 & .82 & .86 & .75 & .79 & .88 & .80 & .84 & .8 \\
\hline .91 & Catalan (CA) & & .77 & .77 & .74 & .77 & .75 & .81 & .84 & .76 & .65 & .75 & .80 & .72 & .77 & .74 & .82 & .84 & .86 & .74 & .75 & .81 & .84 & .82 & .78 \\
\hline .92 & Danish (DA) & & & .88 & .86 & .85 & .84 & .83 & .87 & .81 & .72 & .82 & .78 & .76 & .79 & .76 & .87 & .85 & .87 & .78 & .79 & .85 & .80 & .90 & .80 \\
\hline .92 & Dutch (NL) & & & & .85 & .83 & .84 & .89 & .84 & .79 & .72 & .82 & .76 & .76 & .80 & .75 & .90 & .84 & .86 & .78 & .80 & .85 & .78 & .88 & .77 \\
\hline .99 & $\begin{array}{l}\text { English } \\
\text { (British) } \\
\text { (EN BR) }\end{array}$ & & & & & .91 & .82 & .83 & .83 & .81 & .66 & .75 & .80 & .69 & .84 & .70 & .84 & .82 & .85 & .79 & .80 & .84 & .82 & .84 & .76 \\
\hline .94 & $\begin{array}{l}\text { English (South } \\
\text { African) } \\
\text { (EN SA) }\end{array}$ & & & & & & .81 & .82 & .83 & .81 & .67 & .78 & .77 & .74 & .78 & .73 & .83 & .83 & .85 & .84 & .79 & .84 & .81 & .85 & .78 \\
\hline .94 & Finnish (FI) & & & & & & & .86 & .81 & .78 & .70 & .81 & .76 & .75 & .77 & .74 & .90 & .86 & .86 & .80 & .77 & .87 & .76 & .88 & .79 \\
\hline .92 & German (DE) & & & & & & & & .87 & .82 & .77 & .78 & .76 & .77 & .82 & .76 & .91 & .89 & .89 & .80 & .84 & .88 & .83 & .87 & .82 \\
\hline .89 & Greek (EL) & & & & & & & & & .83 & .66 & .79 & .77 & .84 & .90 & .76 & .84 & .93 & .90 & .79 & .84 & .90 & .85 & .82 & .86 \\
\hline .96 & Hebrew (HE) & & & & & & & & & & .65 & .71 & .68 & .73 & .78 & .70 & .80 & .90 & .85 & .79 & .75 & .81 & .84 & .81 & .78 \\
\hline .87 & $\begin{array}{l}\text { Hungarian } \\
\text { (HU) }\end{array}$ & & & & & & & & & & & .66 & .64 & .70 & .62 & .68 & .73 & .69 & .72 & .70 & .69 & .78 & .69 & .71 & .68 \\
\hline .91 & Icelandic (IS) & & & & & & & & & & & & .77 & .70 & .71 & .72 & .85 & .77 & .78 & .77 & .73 & .83 & .71 & .83 & .75 \\
\hline .78 & Irish (GA) & & & & & & & & & & & & & .78 & .73 & .76 & .83 & .82 & .80 & .70 & .72 & .76 & .76 & .75 & .79 \\
\hline .68 & isiXhosa (XH) & & & & & & & & & & & & & & .68 & .67 & .79 & .81 & .78 & .71 & .74 & .76 & .75 & .77 & .79 \\
\hline .93 & Italian (IT) & & & & & & & & & & & & & & & .65 & .83 & .90 & .87 & .73 & .80 & .84 & .81 & .77 & .75 \\
\hline .92 & Lithuanian (LT) & & & & & & & & & & & & & & & & .78 & .71 & .80 & .83 & .76 & .83 & .73 & .79 & .76 \\
\hline .91 & $\begin{array}{l}\text { Luxembourgish } \\
\text { (LB) }\end{array}$ & & & & & & & & & & & & & & & & & .91 & .91 & .83 & .82 & .91 & .82 & .91 & .82 \\
\hline .75 & Maltese (MT) & & & & & & & & & & & & & & & & & & .91 & .75 & .81 & .86 & .88 & .85 & .83 \\
\hline .91 & Polish (PL) & & & & & & & & & & & & & & & & & & & .84 & .87 & .96 & .85 & .88 & .85 \\
\hline .95 & Russian (RU) & & & & & & & & & & & & & & & & & & & & .78 & .88 & .77 & .84 & .78 \\
\hline .93 & Serbian (SR) & & & & & & & & & & & & & & & & & & & & & .90 & .80 & .84 & .75 \\
\hline .89 & Slovak (SK) & & & & & & & & & & & & & & & & & & & & & & .83 & .91 & .82 \\
\hline .92 & Spanish (ES) & & & & & & & & & & & & & & & & & & & & & & & .80 & .82 \\
\hline .90 & Swedish (SV) & & & & & & & & & & & & & & & & & & & & & & & & .8 \\
\hline .93 & Turkish (TR) & & & & & & & & & & & & & & & & & & & & & & & & \\
\hline
\end{tabular}

All correlations are significant at $p<.001$. Spearman's rank correlation coefficients adjusted for split-half reliabilities higher than .85 are printed in bold 

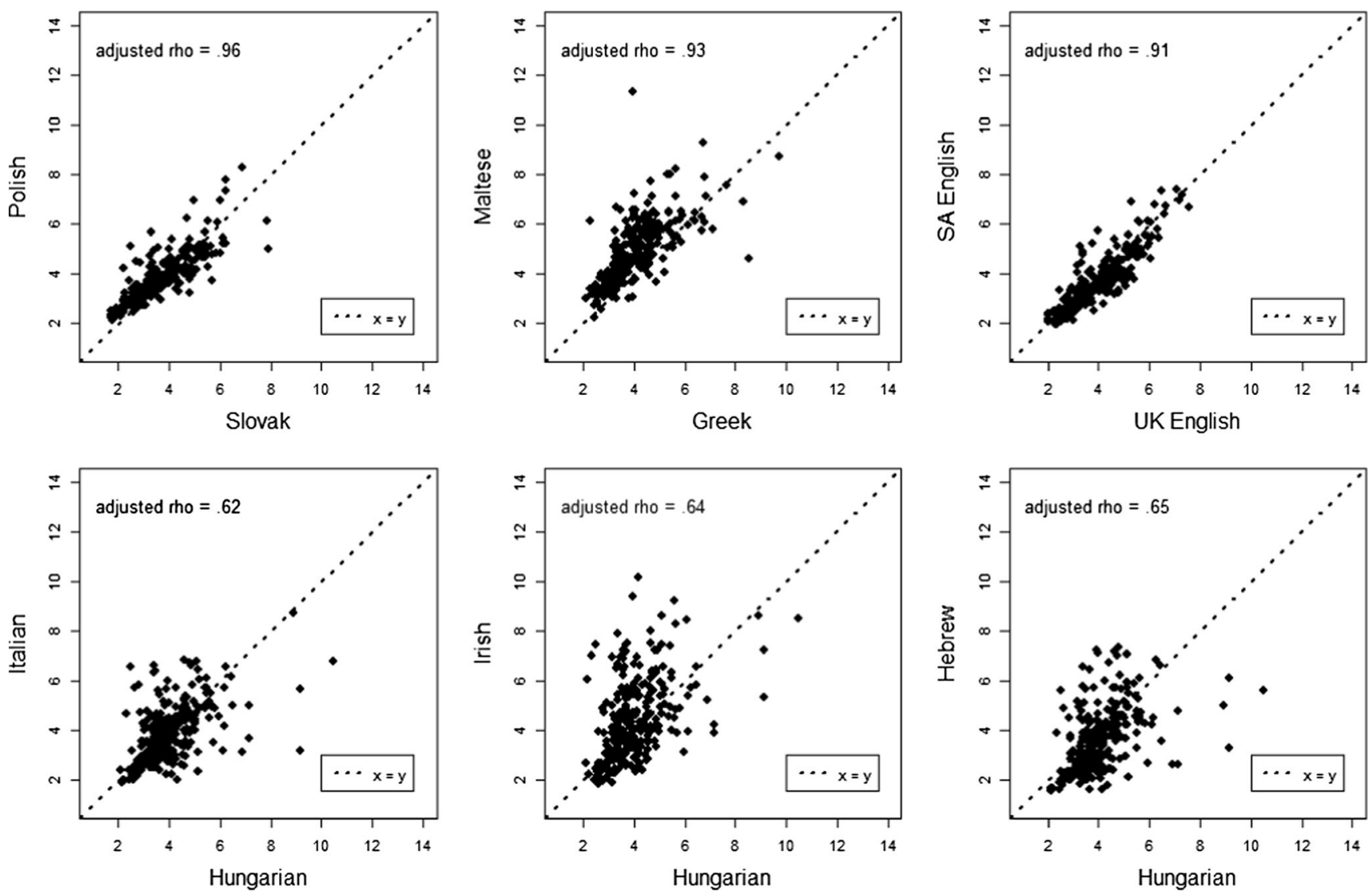

Fig. 1 Highest (upper row) and lowest (lower row) correlations in language pairs

\section{Target questions}

To account for possible differences in the results due to the forms of the target questions, we conducted a control study in which 23 Polish participants answered the modified target question (i.e., (1) "When did you learn this word?" was replaced with (2) "When do children learn this word?"). Their AoA ratings were compared to those of the 32 Polish speakers who answered the original question. The groups differed in age $\left(M_{1}=38.61, S D_{1}=10.65 ; M_{2}=24.94, S D_{2}=7.28 ; t=\right.$ $6.10, p<.001)$ and years of education $\left(M_{1}=17.09, S D_{1}=\right.$ 2.09; $\left.M_{2}=13.91, S D_{2}=2.33 ; t=5.21, p<.001\right)$, but not in gender $\left[\chi^{2}(1, N=55)=0.09, p=.77\right]$, parenting $\left[\chi^{2}(1, N=\right.$ $55)=0.26, p=.61]$, or number of known languages $\left[\chi^{2}(1, N=\right.$ $55)=0.01, p=.93]$.

The results showed that although the two sets of ratings are strongly correlated $\left(r_{\mathrm{S}}=.93, p<.001\right)$, they differ significantly in terms of absolute numbers (see Fig. 3). It appears that

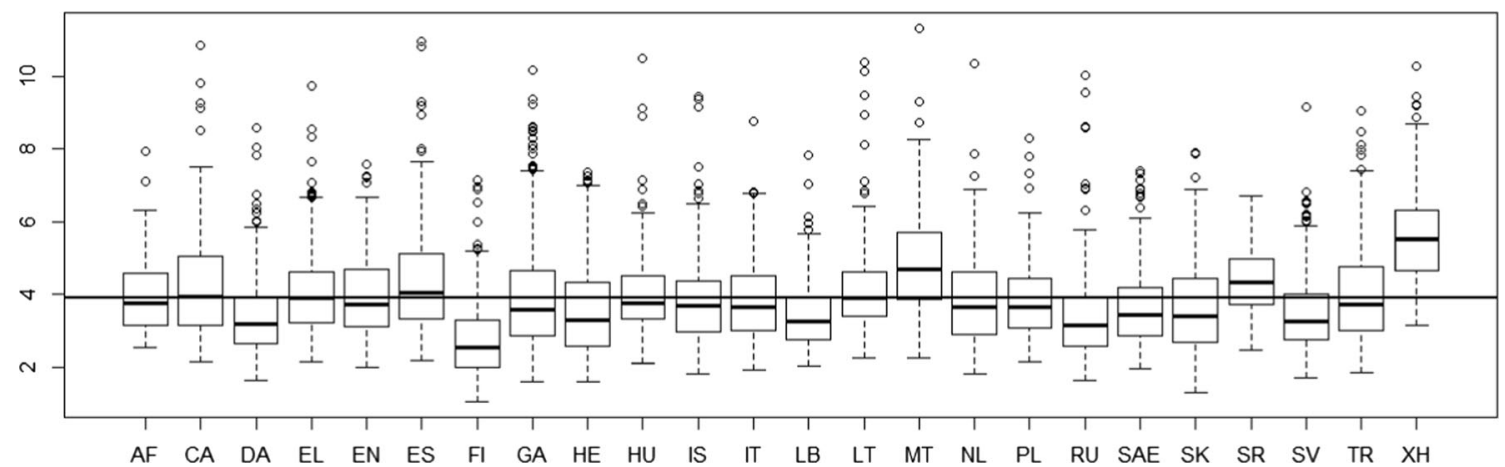

Fig. 2 Means for age-of-acquisition ratings across 25 languages. The dots represent words that are outliers. The horizontal line shows the overall mean for all languages. $\mathrm{AF}=$ Afrikaans, $\mathrm{CA}=$ Catalan, $\mathrm{DA}=$ Danish, $\mathrm{EL}=$ Greek, $\mathrm{EN}=$ British English, $\mathrm{ES}=$ Spanish, $\mathrm{FI}=$ Finnish, $\mathrm{GA}=$

Irish, $\mathrm{HE}=$ Hebrew, HU = Hungarian, IS = Icelandic, IT = Italian, LB = Luxembourgish, $\mathrm{LT}=$ Lithuanian, $\mathrm{MT}=$ Maltese, $\mathrm{NL}=$ Dutch, $\mathrm{PL}=$ Polish, RU = Russian, SAE = South African English, SK = Slovak, SR $=$ Serbian, $\mathrm{SV}=$ Swedish, $\mathrm{TR}=$ Turkish, $\mathrm{XH}=$ isiXhosa 


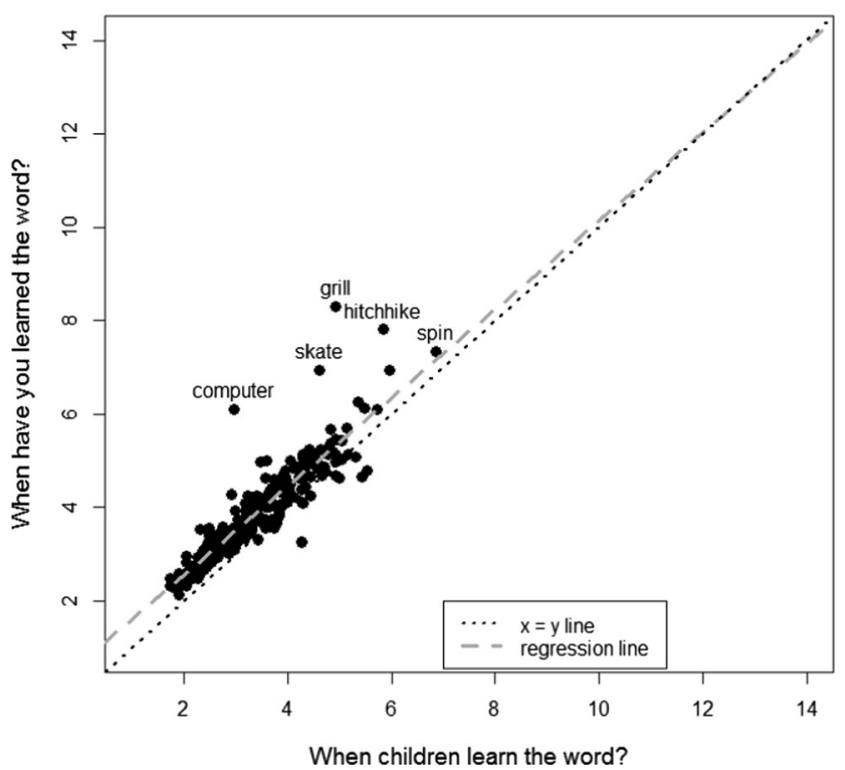

Fig. 3 Relation between two different target questions (Polish control study)

participants reporting their own experience in word learning provided significantly higher AoA ratings than did those assessing when children acquire the words $\left(M_{1}=3.84, S D_{1}\right.$ $\left.=1.0 ; M_{2}=3.34, S D_{2}=0.95 ; t=6.09, p<.001\right)$. This trend was observed for $92 \%$ of the words (see Fig. 3).

\section{Reliability of the data}

To check the reliability of participants' ratings, we randomly divided participants into two groups. The correlations in the AoA ratings between the groups were very high and were significant for both nouns $\left[r_{\mathrm{S}}(156)=.99, p<.001\right]$ and verbs $\left[r_{\mathrm{S}}(139)=.99, p<.001\right]$.

This procedure was repeated to calculate the split-half reliability coefficients per language. The coefficients were, in general, very high (Table 5). For 22 out of the 25 languages, the coefficients were higher than .90 . The only coefficients lower than .85 were obtained for isiXhosa $\left[r_{\mathrm{S}}(297)=.68, p\right.$ $<.001]$, Maltese $\left[r_{\mathrm{S}}(295)=.75, p<.001\right]$, and Irish $\left[r_{\mathrm{S}}(295)=\right.$ $.78, p<.001]$.

\section{AoA ratings versus demographic variables: Gender}

We compared the estimations provided by all male participants $(N=168)$ to those provided by female participants matched to them by age $\left(M_{1}=30.64, S D_{1}=12.43 ; M_{2}=\right.$ $\left.31.17, S D_{2}=12.12 ; t=0.49, p=.69\right)$, education level $\left(M_{1}=\right.$ $\left.15.30, S D_{1}=4.64 ; M_{2}=15.24, S D_{2}=4.78 ; t=0.35, p=.94\right)$, and first language. We found no significant difference in the mean ratings provided by men and women $\left(M_{1}=4.18, S D_{1}=\right.$ $\left.1.13 ; M_{2}=3.96, S D_{2}=1.06 ; t=0.95, p=.06\right)$.

\section{AoA ratings versus demographic variables: Age}

As we assumed, there was no significant correlation between participants' ages and the average AoA ratings for words $[r(771)=-.07, p=.07]$. To validate our prediction about differences in AoA for particular words, we compared the estimations given by the youngest (18-20 years old, $M=$ $19.3, S D=0.7, N=180,151$ females) to those given by the oldest participants (40-80 years old, $M=52.2, S D=8.5, N=$ 140, 102 females). The results (Table 6, Fig. 4) validated our hypothesis, although the orders of word acquisition were similar in the two groups $\left[r_{\mathrm{S}}(297)=.89, p<.001\right]$.

\section{AoA ratings versus demographical variables: Education}

No relationship was found between the estimated AoA of words and participants' education measured in years $[r(771)$ $=-.05, p=.16]$.

\section{AoA ratings versus demographic variables: Parenting}

To check whether being a parent affects AoA ratings, we selected 119 participants who reported that they had at least

Table 6 List of 19 words with significantly different age-of-acquisition ratings between the youngest and oldest participants

\begin{tabular}{|c|c|c|c|c|c|c|}
\hline \multirow[t]{2}{*}{ Word } & \multicolumn{2}{|c|}{ Youngest } & \multicolumn{2}{|l|}{ Oldest } & \multirow[t]{2}{*}{ Difference } & \multirow[t]{2}{*}{$t$} \\
\hline & $M$ & $S D$ & $M$ & $S D$ & & \\
\hline computer & 5.76 & 2.42 & 13.33 & 5.60 & -7.56 & $-16.07^{* * *}$ \\
\hline pizza & 4.69 & 2.17 & 10.49 & 5.62 & -5.81 & $-12.46^{* * *}$ \\
\hline surf & 6.03 & 2.60 & 9.43 & 5.69 & -3.40 & $-6.38^{* * *}$ \\
\hline play golf & 5.23 & 2.49 & 7.72 & 4.95 & -2.49 & $-5.29^{* * *}$ \\
\hline television & 3.44 & 1.50 & 5.22 & 3.77 & -1.79 & $-5.25^{* * *}$ \\
\hline sewing machine & 5.78 & 2.22 & 4.34 & 1.99 & 1.44 & $5.99^{* * *}$ \\
\hline fry & 5.26 & 1.74 & 3.90 & 1.89 & 1.37 & $6.65^{* * *}$ \\
\hline boil & 5.18 & 1.85 & 3.83 & 1.85 & 1.36 & $6.46^{* * *}$ \\
\hline knit & 5.32 & 1.89 & 3.99 & 2.22 & 1.33 & $5.73^{* * *}$ \\
\hline thermometer & 5.83 & 2.61 & 4.56 & 2.37 & 1.27 & $4.42^{* * *}$ \\
\hline needle & 4.85 & 1.90 & 3.65 & 1.42 & 1.20 & $6.17^{* * *}$ \\
\hline grate & 5.25 & 2.02 & 4.09 & 2.40 & 1.16 & $4.65^{* * *}$ \\
\hline sew & 4.99 & 1.92 & 3.85 & 1.81 & 1.14 & $5.37^{* * *}$ \\
\hline shave & 5.56 & 2.28 & 4.44 & 2.41 & 1.12 & $4.21^{* * *}$ \\
\hline peel & 4.76 & 1.95 & 3.66 & 1.60 & 1.10 & $5.33^{* * *}$ \\
\hline sweep & 4.52 & 1.79 & 3.45 & 1.44 & 1.07 & $5.72^{* * *}$ \\
\hline comb & 3.89 & 1.44 & 2.84 & 1.18 & 1.05 & $6.98^{* * *}$ \\
\hline sweater & 4.40 & 1.87 & 3.37 & 2.22 & 1.04 & $4.14^{* * *}$ \\
\hline stir & 4.56 & 2.13 & 3.55 & 1.40 & 1.01 & $4.83^{* * *}$ \\
\hline
\end{tabular}

All other words in the sample were assessed as being acquired at approximately the same ages by both groups. ${ }^{* * *} p<.001$ with Bonferroni correction 


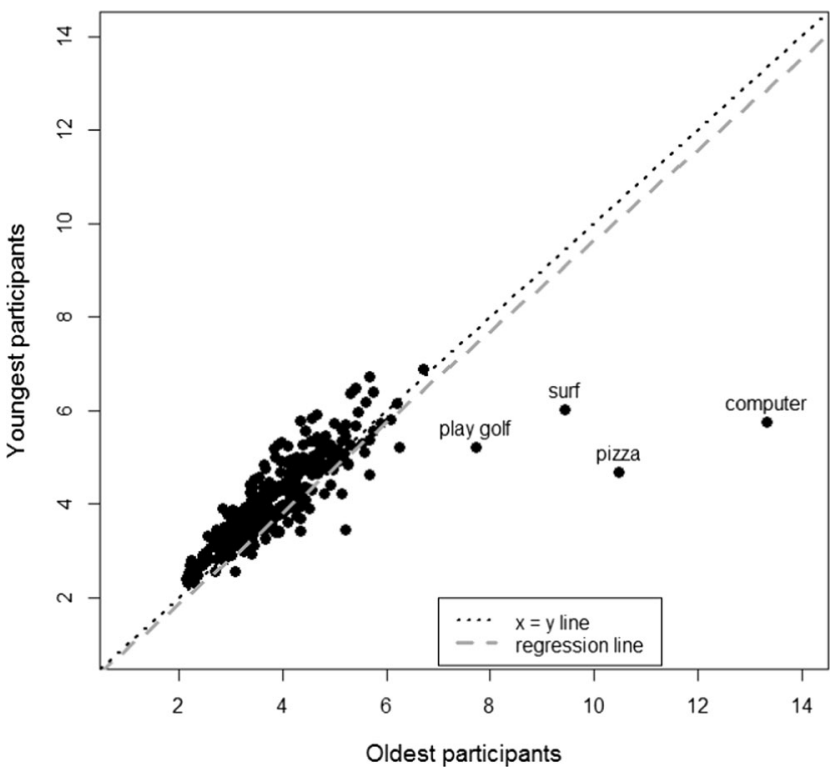

Fig. 4 Age-of-acquisition estimations in different age groups

one child younger than 10 years of age (i.e., their youngest child had to be maximally 10 years old). We chose this criterion to include only participants who had relatively recent memories of their children acquiring vocabulary. This group of parents was compared to a control group of participants speaking the same language who were matched in age $\left(M_{1}=\right.$ 36.11, $S D_{1}=6.83 ; M_{2}=36.36, S D_{2}=10.36 ; t=-0.22, p=$ $.82)$, education $\left(M_{1}=16.29, S D_{1}=4.53 ; M_{2}=16.16, S D_{2}=\right.$ 4.63; $t=0.21, p=.83)$, and gender $\left[\chi^{2}(1, N=238)=1.68, p=\right.$ $.38]$. In the control group, 32 participants reported that they had children between 11 and 32 years of age, and the remaining 87 participants did not have children.

It emerged that the parents of children in preschool and in the early school years judged that they had learned the target words earlier than did the control group. They reported acquiring 294 out of the 299 words (99\%) earlier than the control group, and the mean rating provided by parents was significantly lower than that provided by nonparents $\left(M_{1}=3.41, S D_{1}\right.$ $\left.=1.21 ; M_{2}=3.94, S D_{2}=1.15 ; t=-3.44, p<.001\right)$. However, the orders of word acquisition were almost exactly the same in both groups $\left[r_{\mathrm{S}}(297)=.98, p<.001\right.$, see Fig. 5].

\section{AoA ratings versus demographic variables: Participants' languages}

When asked about their language skills, 376 participants $(49 \%)$ reported that they could speak one language at nativelike level, 293 (38\%) two languages, and 90 (12\%) three languages. Nine people reported that they spoke four or more languages at a native level, and five did not answer this question. To check whether the number of languages spoken affected the estimations of AoA in the first language, we divided

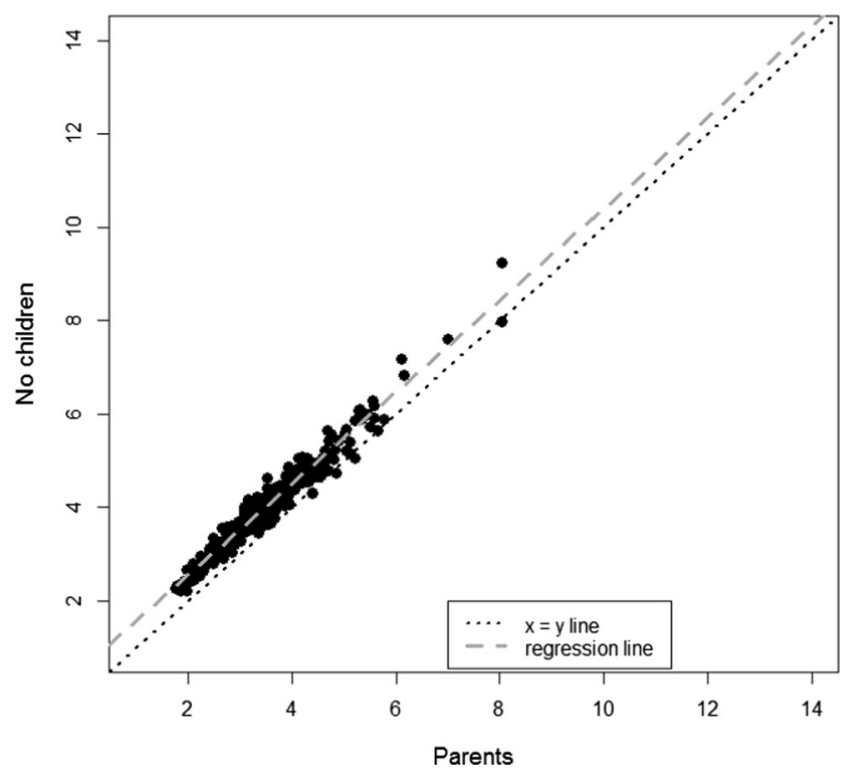

Fig. 5 Age-of-acquisition estimations from people with and without children younger than 10 years of age

the participants into groups: those speaking one language and those speaking two or three languages.

The groups of monolinguals and bi- or trilinguals did not differ in terms of age $\left(M_{1}=29.0, S D_{1}=11.7 ; M_{2}=30.6, S D_{2}=\right.$ $12.9 ; t=-1.85, p=.06)$ and education $\left(M_{1}=15.4, S D_{1}=3.9\right.$; $\left.M_{2}=15.2, S D_{2}=4.0 ; t=-0.76, p=.45\right)$. However, multilingual participants systematically reported that they had acquired words later than monolinguals: They estimated a higher AoA for 288 words $(96 \%)$. The difference in mean ratings by the two groups was significant $\left(M_{1}=3.72, S D_{1}=\right.$ $\left.0.97 ; M_{2}=4.05, S D_{2}=0.98 ; t=-4.19, p<.001\right)$. Again, the results of the two groups were highly correlated $\left[r_{\mathrm{S}}(297)=\right.$ $.98, p<.001]$.

\section{Correlations with previous AoA data}

In order to assess their validity, the AoA ratings were compared with previous AoA norms. From all of the AoA norms available that were mentioned in the introduction, we selected the ones that contained at least 30 words from our sample collected in the same languages. Thus, we correlated our data with previous norms for Dutch, English, German, Greek, Icelandic, Italian, Russian, Spanish, and Turkish (Table 7).

The coefficients were calculated separately for nouns and for verbs. Our ratings were significantly correlated with previous data in the same and in very closely related languages (American and British English, European and Mexican Spanish). We obtained significant and high correlations with existing AoA norms that included both subjective and objective AoA estimations. Correlations with objective AoA (eight studies, range $=.44-.63, M=.56$ ) were slightly lower than those with the subjective ratings (33 studies, range $=.29-.92$, 
Table 7 Correlation coefficients (Pearson's $r$ ) between our age-of-acquisition (AoA) ratings and previous data

\begin{tabular}{|c|c|c|c|c|c|}
\hline Language & & Type of AoA Rating & Part of Speech & $N$ & $r$ \\
\hline \multirow[t]{7}{*}{ Dutch } & Brysbaert et al. (2014) & Subjective & $\mathrm{N}$ & 44 & $.69^{* * *}$ \\
\hline & & & $\mathrm{V}$ & 45 & $.78^{* * *}$ \\
\hline & Ghyselinck et al. (2000) & Subjective & $\mathrm{N}$ & 84 & $.29^{* *}$ \\
\hline & Ghyselinck et al. (2003) & Subjective & $\mathrm{N}$ & 102 & $.91^{* * *}$ \\
\hline & Moors et al. (2013) & Subjective & $\mathrm{N}$ & 115 & $.41^{* * *}$ \\
\hline & & & $\mathrm{V}$ & 102 & $.68^{* * *}$ \\
\hline & Shao et al. (2014) & Subjective & $\mathrm{V}$ & 86 & $.80^{* * *}$ \\
\hline \multirow[t]{16}{*}{ English } & Bird et al. (2001) & Subjective & $\mathrm{V}$ & 79 & $.86^{* * *}$ \\
\hline & Cortese and Khanna (2008) & Subjective & $\mathrm{N}$ & 78 & $.85^{* * *}$ \\
\hline & & Subjective & $\mathrm{V}$ & 114 & $.83^{* * *}$ \\
\hline & Gilhooly and Logie (1980) & Subjective & $\mathrm{N}$ & 50 & $.86^{* * *}$ \\
\hline & & & $\mathrm{V}$ & 34 & $.69^{* * *}$ \\
\hline & Iyer et al. (2001) & Subjective & $\mathrm{N}$ & 139 & $.80^{* * *}$ \\
\hline & Johnston et al. (2010) & Subjective & $\mathrm{N}$ & 139 & $.85^{* * *}$ \\
\hline & Kuperman et al. (2012) & Subjective & $\mathrm{N}$ & 155 & $.75^{* * *}$ \\
\hline & & & $\mathrm{V}$ & 140 & $.81^{* * *}$ \\
\hline & Morrison et al. (1997) & Objective & $\mathrm{N}$ & 87 & $.59^{* * *}$ \\
\hline & & Objective $(75 \%)$ & $\mathrm{N}$ & 118 & $.63^{* * *}$ \\
\hline & & Subjective & $\mathrm{N}$ & 118 & $.92^{* * *}$ \\
\hline & Salmon et al. (2010) & Subjective & $\mathrm{N}$ & 100 & $.77^{* * *}$ \\
\hline & Schock et al. (2012) & Subjective & $\mathrm{N}$ & 37 & $.58^{* * *}$ \\
\hline & Snodgrass and Yuditsky (1996) & Subjective & $\mathrm{N}$ & 118 & $.84^{* * *}$ \\
\hline & $\begin{array}{l}\text { Stadthagen-Gonzalez, Damian, } \\
\text { Pérez, Bowers, and Marín (2009) }\end{array}$ & Subjective & $\mathrm{V}$ & 47 & $.79^{* * *}$ \\
\hline German & Schröder et al. (2011) & Subjective & $\mathrm{N}$ & 60 & $.71^{* * *}$ \\
\hline Greek & Dimitropoulou et al. (2009) & Subjective & $\mathrm{N}$ & 120 & $.87^{* * *}$ \\
\hline \multirow[t]{2}{*}{ Icelandic } & Pind et al. (2000) & Objective & $\mathrm{N}$ & 116 & $.52^{* * *}$ \\
\hline & & Subjective & $\mathrm{N}$ & 122 & $.84^{* * *}$ \\
\hline \multirow[t]{5}{*}{ Italian } & Barca et al. (2002) & Subjective & $\mathrm{N}$ & 47 & $.68^{* * *}$ \\
\hline & Della Rosa et al. (2010) & Subjective & $\mathrm{N}$ & 53 & $.83^{* * *}$ \\
\hline & Lotto et al. (2010) & Objective & $\mathrm{N}$ & 59 & $.63^{* * *}$ \\
\hline & & Objective $(75 \%)$ & $\mathrm{N}$ & 63 & $.63^{* * *}$ \\
\hline & & Subjective & $\mathrm{N}$ & 65 & $.83^{* * *}$ \\
\hline \multirow[t]{3}{*}{ Russian } & Akinina et al. (2014) & Subjective & V & 104 & $.69^{* * *}$ \\
\hline & Grigoriev and Oshhepkov (2013) & Objective & $\mathrm{N}$ & 122 & $.49^{* * *}$ \\
\hline & Tsaparina et al. (2011) & Subjective & $\mathrm{N}$ & 119 & $.75^{* * *}$ \\
\hline \multirow[t]{9}{*}{ Spanish } & Alonso et al. (2015) & Subjective & $\mathrm{N}$ & 143 & $.92^{* * *}$ \\
\hline & & & $\mathrm{V}$ & 65 & $.82^{* * *}$ \\
\hline & Álvarez and Cuetos (2007) & Objective & $\mathrm{N}$ & 121 & $.44^{* * *}$ \\
\hline & Cuetos et al. (1999) & Subjective & $\mathrm{N}$ & 99 & $.85^{* * *}$ \\
\hline & Cuetos et al. (2012) & Subjective & $\mathrm{N}$ & 112 & $.55^{* * *}$ \\
\hline & Manoiloff et al. (2010) & Subjective & $\mathrm{N}$ & 115 & $.61^{* * *}$ \\
\hline & Moreno-Martínez et al. (2014) & Subjective & $\mathrm{N}$ & 85 & $.78^{* * *}$ \\
\hline & Pérez and Navalon (2005) & Objective & $\mathrm{N}$ & 76 & $.52^{* * *}$ \\
\hline & & Subjective & $\mathrm{N}$ & 76 & $.53^{* * *}$ \\
\hline Turkish & Raman et al. (2014) & Subjective & $\mathrm{N}$ & 119 & $.72^{* * *}$ \\
\hline
\end{tabular}

$N=$ number of words for which comparisons were possible; Parts of speech: $\mathrm{N}=$ nouns, $\mathrm{V}=$ verbs; Objective $(75 \%)=$ objective AoA, defined as the age at which $75 \%$ of the children in a given age group knew the word (Morrison et al., 1997). ${ }^{* *} p<.01,{ }^{* * *} p<.001$ 
$M=.75$ ). We found no single study with AoA norms available for which the correlation with our AoA results was not significant.

\section{Correlations with MB-CDI data}

For a given pair of data (MB-CDI vs. AoA), a percentage of children who knew a given word at a certain age (obtained from the MB-CDI norms for that language) was contrasted with the mean AoA of the same word (obtained in the present AoA study). As predicted, a consistent pattern of significant (negative) correlations was found for all data pairs, although in two languages the correlations were significant in some age groups only. Table 8 presents exact values of the coefficients. All correlations for receptive vocabulary ratings were significant, and they were mostly moderate correlations $(r$ : range $=$ -.18 to $-.59, M=-.43)$. For expressive vocabulary, correlations were in general slightly weaker $(r$ : range $=.10$ to $-.68, M$ $=-.39$ ). The only nonsignificant correlations were obtained for the expressive scores of the youngest age groups (children younger than 10 months) and of some older age groups of Spanish and Turkish speakers (Spanish: 8 to 15 months, Turkish: 8 to 13 months).

\section{Discussion}

In the present study, we presented a new set of subjective AoA ratings for 299 words in 25 languages from five different language families. The ratings are highly reliable in terms of internal consistency, and their validity was confirmed in comparisons with data from previous studies. The presented ratings suggest that, although the languages differ in terms of the absolute AoA of words (as reported by adults), the orders of word learning are very similar across all languages studied in the age range from 0 to 6 years. The latter finding may indirectly support the statement about a universal pattern of early meaning acquisition among languages (Clark, 1979, 1995, 2009). The former effect (differences in the absolute numbers obtained for AoA in different languages; see Fig. 2) may be due to various factors not controlled for in the present study (e.g., cultural biases related to different cultural views of language development). ${ }^{1}$ However, such post-hoc explanations are of a speculative nature, and more cross-linguistic studies assessing objective AoA would be needed to confirm the universality of word order acquisition and/or the cross-linguistic differences in the exact ages when particular words are acquired.

The present article describes the first study in which AoA ratings were obtained for such a wide range of languages with the use of identical procedures. The obtained ratings suggest

\footnotetext{
${ }^{1}$ We thank an anonymous reviewer for pointing out this possibility.
}

Table 8 Correlations (Pearson's $r$ ) between AoA ratings and MB-CDI norms for receptive and expressive word knowledge

\begin{tabular}{|c|c|c|c|c|}
\hline \multirow[t]{2}{*}{ Language } & \multirow[t]{2}{*}{$N$} & \multirow{2}{*}{$\begin{array}{l}\text { Age in } \\
\text { Months }\end{array}$} & \multicolumn{2}{|l|}{$\mathrm{CDI}$} \\
\hline & & & Expressive & Receptive \\
\hline \multirow[t]{34}{*}{ Danish } & \multirow[t]{13}{*}{$116^{\mathrm{a}}$} & 8 & $-.20^{*}$ & $-.37^{* * *}$ \\
\hline & & 9 & -.09 & $-.31^{* * *}$ \\
\hline & & 10 & $-.21^{*}$ & $-.37^{* * *}$ \\
\hline & & 11 & $-.21^{*}$ & $-.42^{* * *}$ \\
\hline & & 12 & $-.34^{* * *}$ & $-.47^{* * *}$ \\
\hline & & 13 & $-.30^{* *}$ & $-.45^{* * *}$ \\
\hline & & 14 & $-.31^{* * *}$ & $-.50^{* * *}$ \\
\hline & & 15 & $-.38^{* * *}$ & $-.52^{* * * *}$ \\
\hline & & 16 & $-.42^{* * *}$ & $-.54^{* * *}$ \\
\hline & & 17 & $-.43^{* * *}$ & $-.55^{* * * *}$ \\
\hline & & 18 & $-.48^{* * *}$ & $-.56^{* * *}$ \\
\hline & & 19 & $-.50^{* * *}$ & $-.57^{* * *}$ \\
\hline & & 20 & $-.57^{* * *}$ & $-.58^{* * * *}$ \\
\hline & \multirow[t]{21}{*}{$149^{\mathrm{b}}$} & 16 & $-.44^{* * *}$ & \\
\hline & & 17 & $-.48^{* * *}$ & \\
\hline & & 18 & $-.51^{* * *}$ & \\
\hline & & 19 & $-.53^{* * *}$ & \\
\hline & & 20 & $-.56^{* * *}$ & \\
\hline & & 21 & $-.58^{* * *}$ & \\
\hline & & 22 & $-.61^{* * *}$ & \\
\hline & & 23 & $-.60^{* * *}$ & \\
\hline & & 24 & $-.61^{* * *}$ & \\
\hline & & 25 & $-.59^{* * *}$ & \\
\hline & & 26 & $-.58^{* * *}$ & \\
\hline & & 27 & $-.57^{* * *}$ & \\
\hline & & 28 & $-.55^{* * *}$ & \\
\hline & & 29 & $-.53^{* * *}$ & \\
\hline & & 30 & $-.50^{* * *}$ & \\
\hline & & 31 & $-.49^{* * *}$ & \\
\hline & & 32 & $-.46^{* * *}$ & \\
\hline & & 33 & $-.41^{* * *}$ & \\
\hline & & 34 & $-.42^{* * *}$ & \\
\hline & & 35 & $-.39^{* * *}$ & \\
\hline & & 36 & $-.38^{* * *}$ & \\
\hline \multirow[t]{12}{*}{ German } & \multirow[t]{12}{*}{$152^{\mathrm{b}}$} & 18 & $-.40^{* * *}$ & \\
\hline & & 19 & $-.46^{* * *}$ & \\
\hline & & 20 & $-.39^{* * *}$ & \\
\hline & & 21 & $-.41^{* * *}$ & \\
\hline & & 22 & $-.40^{* * *}$ & \\
\hline & & 23 & $-.43^{* * *}$ & \\
\hline & & 24 & $-.44^{* * *}$ & \\
\hline & & 25 & $-.42^{* * *}$ & \\
\hline & & 26 & $-.46^{* * *}$ & \\
\hline & & 27 & $-.44^{* * *}$ & \\
\hline & & 28 & $-.45^{* * *}$ & \\
\hline & & 29 & $-.43^{* * *}$ & \\
\hline
\end{tabular}


Table 8 (continued)

\begin{tabular}{|c|c|c|c|c|}
\hline \multirow[t]{2}{*}{ Language } & \multirow[t]{2}{*}{$N$} & \multirow{2}{*}{$\begin{array}{l}\text { Age in } \\
\text { Months }\end{array}$} & \multicolumn{2}{|l|}{ CDI } \\
\hline & & & Expressive & Receptive \\
\hline & & 30 & $-.42^{* * *}$ & \\
\hline \multirow[t]{19}{*}{ Italian } & $154^{\mathrm{b}}$ & 18 & $-.39^{* * *}$ & \\
\hline & & 19 & $-.33^{* * *}$ & \\
\hline & & 20 & $-.41^{* * *}$ & \\
\hline & & 21 & $-.46^{* * *}$ & \\
\hline & & 22 & $-.48^{* * *}$ & \\
\hline & & 23 & $-.53^{* * *}$ & \\
\hline & & 24 & $-.53^{* * *}$ & \\
\hline & & 25 & $-.54^{* * *}$ & \\
\hline & & 26 & $-.50^{* * *}$ & \\
\hline & & 27 & $-.50^{* * *}$ & \\
\hline & & 28 & $-.48^{* * *}$ & \\
\hline & & 29 & $-.49^{* * *}$ & \\
\hline & & 30 & $-.51^{* * *}$ & \\
\hline & & 31 & $-.41^{* * *}$ & \\
\hline & & 32 & $-.49^{* * *}$ & \\
\hline & & 33 & $-.49^{* * *}$ & \\
\hline & & 34 & $-.41^{* * *}$ & \\
\hline & & 35 & $-.40^{* * *}$ & \\
\hline & & 36 & $-.41^{* * *}$ & \\
\hline \multirow[t]{27}{*}{ Russian } & $87^{\mathrm{a}}$ & 8 & -.15 & $-.55^{* * *}$ \\
\hline & & 9 & -.21 & $-.51^{* * * *}$ \\
\hline & & 10 & $-.31^{* *}$ & $-.50^{* * *}$ \\
\hline & & 11 & $-.30^{* *}$ & $-.51^{* * *}$ \\
\hline & & 12 & $-.30^{* *}$ & $-.48^{* * *}$ \\
\hline & & 13 & $-.29^{* *}$ & $-.52^{* * * *}$ \\
\hline & & 14 & $-.33^{* *}$ & $-.52^{* * * *}$ \\
\hline & & 15 & $-.35^{* * *}$ & $-.47^{* * * *}$ \\
\hline & & 16 & $-.38^{* * *}$ & $-.50^{* * *}$ \\
\hline & & 17 & $-.38^{* * *}$ & $-.52^{* * * *}$ \\
\hline & & 18 & $-.31^{* *}$ & $-.45^{* * *}$ \\
\hline & $144^{\mathrm{b}}$ & 18 & $-.22^{* *}$ & \\
\hline & & 19 & $-.35^{* * *}$ & \\
\hline & & 20 & $-.36^{* * *}$ & \\
\hline & & 21 & $-.29^{* * *}$ & \\
\hline & & 22 & $-.39^{* * *}$ & \\
\hline & & 23 & $-.36^{* * *}$ & \\
\hline & & 24 & $-.36^{* * *}$ & \\
\hline & & 25 & $-.38^{* * *}$ & \\
\hline & & 26 & $-.37^{* * *}$ & \\
\hline & & 27 & $-.41^{* * *}$ & \\
\hline & & 28 & $-.40^{* * *}$ & \\
\hline & & 29 & $-.39^{* * *}$ & \\
\hline & & 30 & $-.41^{* * *}$ & \\
\hline & & 31 & $-.40^{* * *}$ & \\
\hline & & 32 & $-.48^{* * *}$ & \\
\hline & & 33 & $-.40^{* * *}$ & \\
\hline
\end{tabular}

Table 8 (continued)

\begin{tabular}{|c|c|c|c|c|}
\hline \multirow[t]{2}{*}{ Language } & \multirow[t]{2}{*}{$N$} & \multirow{2}{*}{$\begin{array}{l}\text { Age in } \\
\text { Months }\end{array}$} & \multicolumn{2}{|l|}{ CDI } \\
\hline & & & Expressive & Receptive \\
\hline \multirow{12}{*}{ Swedish } & \multirow{12}{*}{$112^{\mathrm{a}}$} & 34 & $-.50^{* * *}$ & \\
\hline & & 35 & $-.45^{* * *}$ & \\
\hline & & 36 & $-.40^{* * *}$ & \\
\hline & & 8 & NA & $-.31^{* * *}$ \\
\hline & & 9 & -.02 & $-.24^{*}$ \\
\hline & & 10 & $-.22^{*}$ & $-.42^{* * *}$ \\
\hline & & 11 & NA & $-.28^{* *}$ \\
\hline & & 12 & $-.29^{* *}$ & $-.50^{* * *}$ \\
\hline & & 13 & $-.23^{*}$ & $-.43^{* * *}$ \\
\hline & & 14 & $-.40^{* * *}$ & $-.56^{* * *}$ \\
\hline & & 15 & $-.34^{* * *}$ & $-.54^{* * *}$ \\
\hline & & 16 & $-.46^{* * *}$ & $-.59^{* * * *}$ \\
\hline \multirow[t]{30}{*}{ Turkish } & \multirow[t]{9}{*}{$95^{\mathrm{a}}$} & 8 & -.04 & $-.18^{*}$ \\
\hline & & 9 & .01 & $-.27^{* *}$ \\
\hline & & 10 & -.08 & $-.24^{* *}$ \\
\hline & & 11 & -.10 & $-.27^{* *}$ \\
\hline & & 12 & -.10 & $-.30^{* *}$ \\
\hline & & 13 & -.11 & $-.31^{* *}$ \\
\hline & & 14 & $-.21^{*}$ & $-.32^{* * * *}$ \\
\hline & & 15 & $-.18^{*}$ & $-.32^{* * * *}$ \\
\hline & & 16 & $-.19^{*}$ & $-.33^{* * *}$ \\
\hline & \multirow[t]{21}{*}{$129^{\mathrm{b}}$} & 16 & $-.42^{* * *}$ & \\
\hline & & 17 & $-.42^{* * *}$ & \\
\hline & & 18 & $-.44^{* * *}$ & \\
\hline & & 19 & $-.52^{* * *}$ & \\
\hline & & 20 & $-.52^{* * *}$ & \\
\hline & & 21 & $-.57^{* * *}$ & \\
\hline & & 22 & $-.57^{* * *}$ & \\
\hline & & 23 & $-.60^{* * *}$ & \\
\hline & & 24 & $-.64^{* * *}$ & \\
\hline & & 25 & $-.65^{* * *}$ & \\
\hline & & 26 & $-.67^{* * *}$ & \\
\hline & & 27 & $-.68^{* * *}$ & \\
\hline & & 28 & $-.67^{* * *}$ & \\
\hline & & 29 & $-.66^{* * *}$ & \\
\hline & & 30 & $-.66^{* * *}$ & \\
\hline & & 31 & $-.68^{* * *}$ & \\
\hline & & 32 & $-.66^{* * *}$ & \\
\hline & & 33 & $-.67^{* * *}$ & \\
\hline & & 34 & $-.66^{* * *}$ & \\
\hline & & 35 & $-.65^{* * *}$ & \\
\hline & & 36 & $-.67^{* * *}$ & \\
\hline \multirow{5}{*}{$\begin{array}{l}\text { British English (AoA) - } \\
\text { American English } \\
\text { (MB-CDI) }\end{array}$} & \multirow[t]{5}{*}{$118^{\mathrm{a}}$} & 8 & $-.29^{* *}$ & $-.48^{* * * *}$ \\
\hline & & 9 & -.16 & $-.43^{* * *}$ \\
\hline & & 10 & $-.24^{* *}$ & $-.42^{* * *}$ \\
\hline & & 11 & $-.37^{* * *}$ & $-.45^{* * *}$ \\
\hline & & 12 & $-.34^{* * *}$ & $-.40^{* * *}$ \\
\hline
\end{tabular}


Table 8 (continued)

\begin{tabular}{|c|c|c|c|c|}
\hline \multirow[t]{2}{*}{ Language } & \multirow[t]{2}{*}{$N$} & \multirow{2}{*}{$\begin{array}{l}\text { Age in } \\
\text { Months }\end{array}$} & \multicolumn{2}{|l|}{ CDI } \\
\hline & & & Expressive & Receptive \\
\hline \multirow{47}{*}{$\begin{array}{l}\text { South African English } \\
\text { (AoA) - American } \\
\text { English (MB-CDI) }\end{array}$} & \multirow{21}{*}{$157^{\mathrm{b}}$} & 13 & $-.36^{* * *}$ & $-.43^{* * *}$ \\
\hline & & 14 & $-.44^{* * *}$ & $-.46^{* * *}$ \\
\hline & & 15 & $-.45^{* * *}$ & $-.48^{* * *}$ \\
\hline & & 16 & $-.46^{* * *}$ & $-.44^{* * *}$ \\
\hline & & 17 & $-.43^{* * *}$ & $-.47^{* * *}$ \\
\hline & & 18 & $-.47^{* * *}$ & $-.47^{* * *}$ \\
\hline & & 16 & $-.47^{* * *}$ & \\
\hline & & 17 & $-.53^{* * *}$ & \\
\hline & & 18 & $-.54^{* * *}$ & \\
\hline & & 19 & $-.56^{* * *}$ & \\
\hline & & 20 & $-.55^{* * *}$ & \\
\hline & & 21 & $-.55^{* * *}$ & \\
\hline & & 22 & $-.55^{* * *}$ & \\
\hline & & 23 & $-.57^{* * *}$ & \\
\hline & & 24 & $-.59^{* * *}$ & \\
\hline & & 25 & $-.58^{* * *}$ & \\
\hline & & 26 & $-.56^{* * *}$ & \\
\hline & & 27 & $-.55^{* * *}$ & \\
\hline & & 28 & $-.55^{* * *}$ & \\
\hline & & 29 & $-.55^{* * *}$ & \\
\hline & & 30 & $-.50^{* * *}$ & \\
\hline & \multirow[t]{11}{*}{$118^{\mathrm{a}}$} & 8 & -.16 & $-.49^{* * *}$ \\
\hline & & 9 & -.17 & $-.46^{* * *}$ \\
\hline & & 10 & $-.25^{* *}$ & $-.46^{* * *}$ \\
\hline & & 11 & $-.32^{* * *}$ & $-.46^{* * *}$ \\
\hline & & 12 & $-.34^{* * *}$ & $-.46^{* * *}$ \\
\hline & & 13 & $-.35^{* * *}$ & $-.48^{* * *}$ \\
\hline & & 14 & $-.40^{* * *}$ & $-.52^{* * *}$ \\
\hline & & 15 & $-.41^{* * *}$ & $-.53^{* * *}$ \\
\hline & & 16 & $-.42^{* * *}$ & $-.51^{* * *}$ \\
\hline & & 17 & $-.39^{* * *}$ & $-.51^{* * *}$ \\
\hline & & 18 & $-.41^{* * *}$ & $-.54^{* * *}$ \\
\hline & \multirow[t]{15}{*}{$157^{\mathrm{b}}$} & 16 & $-.45^{* * *}$ & \\
\hline & & 17 & $-.51^{* * *}$ & \\
\hline & & 18 & $-.50^{* * *}$ & \\
\hline & & 19 & $-.55^{* * *}$ & \\
\hline & & 20 & $-.53^{* * *}$ & \\
\hline & & 21 & $-.56^{* * *}$ & \\
\hline & & 22 & $-.56^{* * *}$ & \\
\hline & & 23 & $-.60^{* * *}$ & \\
\hline & & 24 & $-.60^{* * *}$ & \\
\hline & & 25 & $-.59^{* * *}$ & \\
\hline & & 26 & $-.59^{* * *}$ & \\
\hline & & 27 & $-.57^{* * *}$ & \\
\hline & & 28 & $-.55^{* * *}$ & \\
\hline & & 29 & $-.57^{* * *}$ & \\
\hline & & 30 & $-.58^{* * *}$ & \\
\hline
\end{tabular}

Table 8 (continued)

\begin{tabular}{|c|c|c|c|c|}
\hline \multirow[t]{2}{*}{ Language } & \multirow[t]{2}{*}{$N$} & \multirow{2}{*}{$\begin{array}{l}\text { Age in } \\
\text { Months }\end{array}$} & \multicolumn{2}{|l|}{ CDI } \\
\hline & & & Expressive & Receptive \\
\hline \multirow{24}{*}{$\begin{array}{l}\text { Serbian (AoA) - Croatian } \\
\quad(\text { MB-CDI) }\end{array}$} & \multirow[t]{9}{*}{$116^{\mathrm{a}}$} & 8 & NA & $-.25^{* *}$ \\
\hline & & 9 & -.14 & $-.30^{* *}$ \\
\hline & & 10 & $-.27^{* *}$ & $-.43^{* * *}$ \\
\hline & & 11 & -.13 & $-.37^{* * * *}$ \\
\hline & & 12 & $-.34^{* * *}$ & $-.45^{* * *}$ \\
\hline & & 13 & $-.21^{*}$ & $-.47^{* * *}$ \\
\hline & & 14 & $-.29^{* *}$ & $-.44^{* * *}$ \\
\hline & & 15 & $-.29^{* *}$ & $-.47^{* * *}$ \\
\hline & & 16 & $-.43^{* * *}$ & $-.53^{* * *}$ \\
\hline & \multirow[t]{15}{*}{$118^{\mathrm{b}}$} & 16 & $-.51^{* * *}$ & \\
\hline & & 17 & $-.49^{* * *}$ & \\
\hline & & 18 & $-.53^{* * *}$ & \\
\hline & & 19 & $-.57^{* * *}$ & \\
\hline & & 20 & $-.56^{* * *}$ & \\
\hline & & 21 & $-.64^{* * *}$ & \\
\hline & & 22 & $-.57^{* * *}$ & \\
\hline & & 23 & $-.59^{* * *}$ & \\
\hline & & 24 & $-.60^{* * *}$ & \\
\hline & & 25 & $-.58^{* * *}$ & \\
\hline & & 26 & $-.60^{* * *}$ & \\
\hline & & 27 & $-.61^{* * *}$ & \\
\hline & & 28 & $-.53^{* * *}$ & \\
\hline & & 29 & $-.58^{* * *}$ & \\
\hline & & 30 & $-.53^{* * *}$ & \\
\hline \multirow{23}{*}{$\begin{array}{l}\text { European Spanish (AoA) - } \\
\text { Mexican Spanish } \\
\text { (MB-CDI) }\end{array}$} & \multirow[t]{11}{*}{$107^{\mathrm{a}}$} & 8 & .00 & $-.26^{* *}$ \\
\hline & & 9 & -.01 & $-.25^{* *}$ \\
\hline & & 10 & -.01 & $-.30^{* *}$ \\
\hline & & 11 & -.12 & $-.32^{* * *}$ \\
\hline & & 12 & -.09 & $-.37^{* * *}$ \\
\hline & & 13 & -.17 & $-.36^{* * *}$ \\
\hline & & 14 & -.16 & $-.34^{* * *}$ \\
\hline & & 15 & -.16 & $-.38^{* * *}$ \\
\hline & & 16 & $-.22^{*}$ & $-.39^{* * * *}$ \\
\hline & & 17 & $-.27^{* *}$ & $-.41^{* * *}$ \\
\hline & & 18 & $-.25^{* *}$ & $-.43^{* * *}$ \\
\hline & \multirow[t]{12}{*}{$151^{\mathrm{b}}$} & 16 & $-.37^{* * *}$ & \\
\hline & & 17 & $-.40^{* * *}$ & \\
\hline & & 18 & $-.42^{* * *}$ & \\
\hline & & 19 & $-.47^{* * *}$ & \\
\hline & & 20 & $-.49^{* * *}$ & \\
\hline & & 21 & $-.48^{* * *}$ & \\
\hline & & 22 & $-.50^{* * *}$ & \\
\hline & & 23 & $-.51^{* * *}$ & \\
\hline & & 24 & $-.54^{* * *}$ & \\
\hline & & 25 & $-.56^{* * *}$ & \\
\hline & & 26 & $-.57^{* * *}$ & \\
\hline & & 27 & $-.56^{* * *}$ & \\
\hline
\end{tabular}


Table 8 (continued)

\begin{tabular}{lllll}
\hline Language & $N$ & $\begin{array}{l}\text { Age in } \\
\text { Months }\end{array}$ & \multicolumn{2}{l}{ CDI } \\
\cline { 3 - 4 } & & Expressive & Receptive \\
\hline 28 & $-.55^{* * *}$ & \\
29 & $-.56^{* * *}$ & \\
30 & $-.55^{* * *}$ & \\
\hline
\end{tabular}

${ }^{\mathrm{a}}$ Words \& Gestures version. ${ }^{\mathrm{b}}$ Words \& Sentences version. $N=$ number of words for which comparisons were possible; $\mathrm{MB}-\mathrm{CDI}=$ norms (in \%) of children in a monthly age interval who know the words either actively or passively. ${ }^{*} p<.05,{ }^{* *} p<.01,{ }^{* * *} p<.001$, NA = no correlation, because of no variance in the MB-CDI norms (i.e., no children know the words)

that the words included in the study are all acquired earlymostly in the first 7 years of life-in all languages considered. Thus, the ratings obtained in the present study constitute close to a fully comparable database of words across languages, because of both the standardization of the procedures across the languages and the similarity of the results. Thus, the ratings may be used as a measure of "word difficulty" in crosslinguistic studies on word learning or processing by preschool children. The ratings may also be applied in the adaptation of experiments from one language to another, because this process often needs to control for word AoA across languages.

Our analysis also has methodological implications for future AoA studies. It reveals that the target question used widely for obtaining subjective AoA ratings ("When did you learn the word?") may in fact lead participants to an overestimation of AoA. Changing the question to the one concerning word acquisition in children ("When do children learn this word?"), as well as analysis of the responses of parent participants, indicate that existing AoA ratings may yield an overly conservative AoA. Both parents answering the traditional AoA question and participants answering the question about children learning words provided significantly lower AoA estimations.

In contrast to Kuperman et al. (2012), who reported women giving slightly higher estimations of AoA, we found no gender difference in AoA ratings. Comparison of the answers of polarized age groups showed that, in general, AoA estimations are independent of age. This does not support the results reported by Kuperman and colleagues, who found a marginal but significant $(r=.07)$ correlation between participants' age and the AoA ratings that they provided. However, this incongruence may have been affected by the specificity of the word list we applied. The reason for the difference between Kuperman et al.'s and our findings may lie in the type of stimuli used: We used a set of relatively simple words labeling imageable objects or actions, which were acquired early in life. Thus, Kuperman et al.'s explanation of the age differences - that older participants gave higher estimations because they had a broader age range to choose from-is not directly applicable to our data set.
Although, in general, the presented AoA ratings do not depend on participants' ages, the exact AoAs of some words may differ between younger and older adults. In particular, the labels of the most modern objects and activities (e.g., newtech tools) were estimated to be acquired by older people at later stages in their lives, which replicates the results of Bird et al. (2001). Thus, similarly to Cuetos et al. (2012), we suggest that for studies of AoA effects in older participants, appropriate norms should be used rather than those based on estimations obtained from young adults.

As was the case in the results of Kuperman et al. (2012), we did not find any correlation between the education level of the participants and the ratings that they provided. However, in contrast to the study by Kuperman et al., in the present study this result was expected, because the stimuli consisted of simple words typically acquired by toddlers or preschoolers.

Particularly noteworthy was the finding that AoA estimations depended on the number of languages spoken by the participants: The more languages the participants spoke at a native-like level, the higher the AoA they provided. This result is in line with known patterns of lexical development in bilinguals, who may learn some words later than their monolingual peers (Bialystok et al., 2010).

Finally, the correlations with previous subjective and objective AoA ratings, as well as with the MB-CDI norms, validate the present norms in the cases of all languages for which any previous AoA norms or MB-CDI norms are available.

\section{Study limitations}

In the present study, we aimed to collect AoA ratings for a wide range of languages. Because we based our AoA ratings on a set of words selected according to the criterion of sharing meanings across the languages (Haman, SzewczykMieszkowska, et al., in preaparation), nontranslatable words were not included in our word lists. This criterion significantly reduced the number of possible items to only 158 nouns and 141 verbs out of more than 1,000 words. Thus, the number of words used in the present study was limited, especially in comparison to the four most extensive word sets used by Kuperman et al. (2012) and Brysbaert et al. (2014) (30,000), Alonso et al. (2015: 7,149), and Moors et al. (2013: 4,300). However, most AoA studies have used smaller numbers of words, with the average number of items being around 450 , and the median number of items being about 220 (estimated for 60 publications that included ratings for AoA). Given that the words were selected to be translatable across languages, our data set does not contain any items specific for some of the languages and cultures, even those that were included in the naming study by Haman, SzewczykMieszkowska, et al. (in preaparation).

The AoA ratings presented in the present article suggest that all of the words included in our set are typically acquired by the age of 7 years. This makes them all "early words," from 
the point of view of mature speakers, and limits the usability of the present data set in studies of AoA effects in adults. However, the ratings are still appropriate for experiments concerning AoA effects in children in different languages.

\section{Conclusions}

The present study has provided AoA ratings for 158 nouns and 141 verbs in 25 languages. All 299 words were judged as being acquired early in life, mostly at preschool age. This, together with the high validity of the ratings, leads to the conclusion that this article presents a fully comparable database of subjective AoA of 299 words in 25 languages. The database may be useful for a wide range of studies, with both single-language and cross-linguistic designs, in which controlling for stimulus word parameters is required.

Author Note This study was designed as part of a multilingual parallel construction procedure of the LITMUS Cross-Linguistic Lexical Tasks within the networking program COST Action IS0804 "Language Impairment in a Multilingual Society: Linguistic Patterns and the Road to Assessment" (www.bi-sli.org; 2010-2013). The research (website design and maintenance) was supported by the Polish Ministry of Science and Higher Education (Grant No. 809/N-COST/2010/0, awarded to the Faculty of Psychology, University of Warsaw, in cooperation with Institute of Psychology, Jagiellonian University; Principal Investigators: Ewa Haman \& Zofia Wodniecka). We are grateful to all assistants who contributed to participant recruitment and to all informants in the 25 languages who participated in the study.

\section{References}

Adorni, R., Manfredi, M., \& Proverbio, A. M. (2013). Since when or how often? Dissociating the roles of age of acquisition (AoA) and lexical frequency in early visual word processing. Brain and Language, 124, 132-141. doi:10.1016/j.bandl.2012.11.005

Akinina, Y., Malyutina, S., Ivanova, M., Iskra, E., Mannova, E., \& Dragoy, O. (2014). Russian normative data for 375 action pictures and verbs. Behavior Research Methods. doi:10.3758/s13428-0140492-9. Advance online publication.

Aksu-Koç, A., Küntay, A., Acarlar, F., Maviș, İ., Sofu, H., . . . Turan, F. (2009). Türkçe'de erken sözcük ve dilbilgisi gelişimini ölçme ve değerlendirme çalışması türkçe iletişim gelişimi envanterleri: TIGE-I ve TIGE-II [The assessment and evaluation of early lexical and grammatical development in Turkish: The Turkish Communicative Development Inventories, TIGE-I and TIGE-II] (Final report of Project No: 107K058). Ankara, Turkey: Turkish Scientific and Technological Research Foundation.

Alario, F.-X., \& Ferrand, L. (1999). A set of 400 pictures standardized for French: Norms for name agreement, image agreement, familiarity, visual complexity, image variability, and age of acquisition. Behavior Research Methods, Instruments, \& Computers, 31, 531552. doi:10.3758/BF03200732

Alonso, M. A., Fernandez, A., \& Díez, E. (2015). Subjective age-ofacquisition norms for 7,039 Spanish words. Behavior Research Methods, 47, 268-274. doi:10.3758/s13428-014-0454-2
Álvarez, B., \& Cuetos, F. (2007). Objective age of acquisition norms for a set of 328 words in Spanish. Behavior Research Methods, 39, 377 383. doi:10.3758/BF03193006

Assink, E. M., van Well, S., \& Knuijt, P. P. (2003). Age-of-acquisition effects in native speakers and second-language learners. Memory \& Cognition, 31, 1218-1228.

Auer, E. T., Jr., \& Bernstein, L. E. (2008). Estimating when and how words are acquired: A natural experiment on the development of the mental lexicon. Journal of Speech, Language, and Hearing Research, 51, 750-758. doi:10.1044/1092-4388(2008/053)

Bai, L., Ma, T., Dunlap, S., \& Chen, B. (2013). Age of acquisition affects the retrieval of grammatical category information. Quarterly Journal of Experimental Psychology, 66, 786-800. doi:10.1080/ 17470218.2012.719528

Bakhtiar, M., Nilipour, R., \& Weekes, B. S. (2013). Predictors of timed picture naming in Persian. Behavior Research Methods, 45, 834 841. doi:10.3758/s13428-012-0298-6

Barbarotto, R., Laiacona, M., \& Capitani, E. (2005). Objective versus estimated age of word acquisition: A study of 202 Italian children. Behavior Research Methods, 37, 644-650. doi:10.3758/ BF03192735

Barca, L., Burani, C., \& Arduino, L. S. (2002). Word naming times and psycholinguistic norms for Italian nouns. Behavior Research Methods, Instruments, \& Computers, 34, 424-434. doi:10.3758/ BF03195471

Barry, C., \& Gerhand, S. (2003). Both concreteness and age-ofacquisition affect reading accuracy but only concreteness affects comprehension in a deep dyslexic patient. Brain and Language, 84, 84-104.

Barry, C., Morrison, C. M., \& Ellis, A. W. (1997). Naming the Snodgrass and Vanderwart pictures: Effects of age of acquisition, frequency, and name agreement. Quarterly Journal of Experimental Psychology, 50A, 560-585. doi:10.1080/783663595

Barry, C., Hirsh, K. W., Johnston, R. A., \& Williams, C. L. (2001). Age of acquisition, word frequency, and the locus of repetition priming of picture naming. Journal of Memory and Language, 44, 350-375. doi:10.1006/jmla.2000.2743

Barry, C., Johnston, R. A., \& Wood, R. F. (2006). Effects of age of acquisition, age, and repetition priming on object naming. Visual Cognition, 13, 911-927. doi:10.1080/13506280544000101

Bates, E., Burani, C., D’Amico, S., \& Barca, L. (2001). Word reading and picture naming in Italian. Memory \& Cognition, 29, 986-999. doi: 10.3758/BF03195761

Baumeister, A. A. (1984). Age of acquisition and meaningfulness as predictors of word availability. Journal of General Psychology, 112, 109-112.

Belke, E., Brysbaert, M., Meyer, A. S., \& Ghyselinck, M. (2005). Age of acquisition effects in picture naming: Evidence for a lexical-semantic competition hypothesis. Cognition, 96, B45-B54. doi:10.1016/j. cognition.2004.11.006

Bialystok, E., Luk, G., Peets, K. F., \& Yang, S. (2010). Receptive vocabulary differences in monolingual and bilingual children. Bilingualism: Language and Cognition, 13, 525-531.

Bird, H., Franklin, S., \& Howard, D. (2001). Age of acquisition and imageability ratings for a large set of words, including verbs and function words. Behavior Research Methods, Instruments, \& Computers, 33, 73-79. doi:10.3758/BF03195349

Bleses, D., Vach, W., Slott, M., Wehberg, S., Thomsen, P., Madsen, T., \& Basbøll, H. (2008). The Danish Communicative Development Inventories: Validity and main developmental trends. Journal of Child Language, 35, 619-650.

Bogka, N., Masterson, J., Druks, J., Fragkioudaki, M., Chatziprokopiou, E.-S., \& Economou, K. (2003). Object and action picture naming in English and Greek. European Journal of Cognitive Psychology, 15, 371-403. doi:10.1080/09541440303607 
Bonin, P., Fayol, M., \& Chalard, M. (2001). Age of acquisition and word frequency in written picture naming. Quarterly Journal of Experimental Psychology, 54A, 469-489. doi:10.1080/713755968

Bonin, P., Chalard, M., Méot, A., \& Fayol, M. (2002). The determinants of spoken and written picture naming latencies. British Journal of Psychology, 93, 89-114. doi:10.1348/000712602162463

Bonin, P., Peereman, R., Malardier, N., Méot, A., \& Chalard, M. (2003). A new set of 299 pictures for psycholinguistic studies: French norms for name agreement, image agreement, conceptual familiarity, visual complexity, image variability, age of acquisition, and naming latencies. Behavior Research Methods, Instruments, \& Computers, 35 , 158-167. doi:10.3758/BF03195507

Bonin, P., Barry, C., Méot, A., \& Chalard, M. (2004a). The influence of age of acquisition in word reading and other tasks: A never ending story? Journal of Memory and Language, 50, 456-476. doi:10. 1016/j.jml.2004.02.001

Bonin, P., Boyer, B., Méot, A., Fayol, M., \& Droit, S. (2004b). Psycholinguistic norms for action photographs in French and their relationships with spoken and written latencies. Behavior Research Methods, Instruments, \& Computers, 36, 127-139. doi:10.3758/ BF03195558

Bonin, P., Perret, C., Méot, A., Ferrand, L., \& Mermillod, M. (2008). Psycholinguistic norms and face naming times for photographs of celebrities in French. Behavior Research Methods, 40, 137-146. doi:10.3758/BRM.40.1.137

Brown, G. D. A., \& Watson, F. L. (1987). First in, first out: Word learning age and spoken word frequency as predictors of word familiarity and word naming latency. Memory \& Cognition, 15, 208-216. doi:10. 3758/BF03197718

Brysbaert, M. (1996). Word frequency affects naming latency in Dutch when age of acquisition is controlled. European Journal of Cognitive Psychology, 8, 185-194. doi:10.1080/095414496383149

Brysbaert, M., \& Cortese, M. J. (2011). Do the effects of subjective frequency and age of acquisition survive better word frequency norms? Quarterly Journal of Experimental Psychology, 64, 545559. doi:10.1080/17470218.2010.503374

Brysbaert, M., Lange, M., \& Van Wijnendaele, I. (2000a). The effects of age-of-acquisition and frequency-of-occurrence in visual word recognition: Further evidence from the Dutch language. European Journal of Cognitive Psychology, 12, 65-85.

Brysbaert, M., Van Wijnendaele, I., \& De Deyne, S. (2000b). Age-ofacquisition effects in semantic processing tasks. Acta Psychologica, 104, 215-226. doi:10.1016/S0001-6918(00)00021-4

Brysbaert, M., Stevens, M., De Deyne, S., Voorspoels, W., \& Storms, G. (2014). Norms of age of acquisition and concreteness for 30,000 Dutch words. Acta Psychologica, 150, 80-84.

Camaioni, L., Caselli, M. C., Longobardi, E., \& Volterra, V. (1991). A parent report instrument for early language assessment. First Language, 11, 345-359.

Cameirão, M. L., \& Vicente, S. G. (2010). Age-of-acquisition norms for a set of 1,749 Portuguese words. Behavior Research Methods, 42, 474-480. doi:10.3758/BRM.42.2.474

Cannard, C., \& Kandel, S. (2008). Impact of semantic or phonemic cues in picture-naming tasks on the calculation of the objective age-ofacquisition norms: A cross-linguistic study. Behavior Research Methods, 40, 1055-1064. doi:10.3758/BRM.40.4.1055

Carroll, J. B., \& White, M. N. (1973a). Age-of-acquisition norms for 220 picturable nouns. Journal of Verbal Learning and Verbal Behavior, 12, 563-576. doi:10.1016/S0022-5371(73)80036-2

Carroll, J. B., \& White, M. N. (1973b). Word frequency and age of acquisition as determiners of picture-naming latency. Quarterly Journal of Experimental Psychology, 25, 85-95. doi:10.1080/ 14640747308400325

Catling, J. C., South, F., \& Dent, K. (2013). The effect of age of acquisition on older individuals with and without cognitive impairments.
Quarterly Journal of Experimental Psychology, 66, 1963-1973. doi: 10.1080/17470218.2013.771689

Chalard, M., \& Bonin, P. (2006). Age-of-acquisition effects in picture naming: Are they structural and/or semantic in nature? Visual Cognition, 13, 864-883. doi:10.1080/13506280544000084

Chalard, M., Bonin, P., Méot, A., Boyer, B., \& Fayol, M. (2003). Objective age-of-acquisition (AoA) norms for a set of 230 object names in French: Relationships with psycholinguistic variables, the English data from Morrison et al. (1997), and naming latencies. European Journal of Cognitive Psychology, 15, 209-245.

Clark, E. V. (1979). The ontogenesis of meaning. Wiesbaden: Akademische Verlagsgesellschaft Athenaion.

Clark, E. V. (1995). Language acquisition: The lexicon and syntax. In J. L. Miller \& P. D. Eimas (Eds.), Speech, language and communication (pp. 303-337). San Diego: Academic Press.

Clark, E. V. (2001). Emergent categories in first language acquisition. In M. Bowerman \& S. C. Levinson (Eds.), Language acquisition and conceptual development (pp. 379-405). Cambridge: Cambridge University Press.

Clark, E. V. (2009). First language acquisition (2nd ed.). Cambridge: Cambridge University Press.

Colombo, L., \& Burani, C. (2002). The influence of age of acquisition, root frequency, and context availability in processing nouns and verbs. Brain and Language, 81, 398-411. doi:10.1006/brln.2001. 2533

Coltheart, V., Laxon, V. J., \& Keating, C. (1988). Effects of word imageability and age of acquisition on children's reading. British Journal of Psychology, 79, 1-12. doi:10.1111/j.2044-8295.1988. tb02270.x

Cortese, M. J., \& Khanna, M. M. (2007). Age of acquisition predicts naming and lexical-decision performance above and beyond 22 other predictor variables: An analysis of 2,342 words. The Quarterly Journal of Experimental Psychology, 60, 1072-1082. doi:10.1080/ 17470210701315467

Cortese, M. J., \& Khanna, M. M. (2008). Age of acquisition ratings for 3, 000 monosyllabic words. Behavior Research Methods, 40, 791794. doi:10.3758/BRM.40.3.791

Cortese, M. J., \& Schock, J. (2013). Imageability and age of acquisition effects in disyllabic word recognition. Quarterly Journal of Experimental Psychology, 66, 946-972. doi:10.1080/17470218. 2012.722660

Cuetos, F., Ellis, A. W., \& Alvarez, B. (1999). Naming times for the Snodgrass and Vanderwart pictures in Spanish. Behavior Research Methods, Instruments, \& Computers, 31, 650-658. doi:10.3758/ BF03200741

Cuetos, F., Samartino, T., \& Ellis, A. W. (2012). Age acquisition norms from elderly Spanish people: Characteristics and the prediction of word recognition performance in Alzheimer's disease. Psicologica, 33, 59-76. Retrieved from www.uv.es/psicologica/articulos1.12/ 4CUETOS.pdf

D'Amico, S., Devescovi, A., \& Bates, E. (2001). Picture naming and lexical access in Italian children and adults. Journal of Cognition and Development, 2, 71-105. doi:10.1207/S15327647JCD0201_4

Dale, P. S. (1991). The validity of a parent report measure of vocabulary and syntax at 24 months. Journal of Speech, Language, and Hearing Research, 34, 565-571.

Dale, P. S., \& Fenson, L. (1996). Lexical development norms for young children. Behavior Research Methods, Instruments, \& Computers, 28, 125-127. doi:10.3758/BF03203646

Dale, P. S., \& Penfold, M. (2011). Adaptations of the MacArthur-Bates CDI into Non-U.S. English Languages. Retrieved from www.sci. sdsu.edu/cdi/documents/AdaptationsSurvey7-5-11Web.pdf

De Deyne, S., \& Storms, G. (2007). Age-of-acquisition differences in young and older adults affect latencies in lexical decision and semantic categorization. Acta Psychologica, 124, 274-295. doi:10. 1016/j.actpsy.2006.03.007 
De Deyne, S., \& Storms, G. (2008). Word associations: Norms for 1,424 Dutch words in a continuous task. Behavior Research Methods, 40, 198-205. doi:10.3758/BRM.40.1.198

De Moor, W., Ghyselinck, M., \& Brysbaert, M. (2000). A validation study of the age-of-acquisition norms collected by Ghyselinck, De Moor, \& Brysbaert. Psychologica Belgica, 40, 99-114.

Della Rosa, P. A., Catricalà, E., Vigliocco, G., \& Cappa, S. F. (2010). Beyond the abstract - concrete dichotomy: Mode of acquisition, concreteness, imageability, familiarity, age of acquisition, context availability, and abstractness norms for a set of 417 Italian words. Behavior Research Methods, 42, 1042-1048. doi:10.3758/BRM.42. 4.1042

Dimitropoulou, M., Duñabeitia, J. A., Blitsas, P., \& Carreiras, M. (2009). A standardized set of 260 pictures for Modern Greek: Norms for name agreement, age of acquisition, and visual complexity. Behavior Research Methods, 41, 584-589. doi:10.3758/BRM.41. 2.584

Dromi, E., Maital, S. I., Sagi, A., \& Bornstein, M. H. (2000). The Hebrew communicative development inventory: Language specific properties and cross-linguistic generalizations. Journal of Child Language, 27, 43-67.

Eliseeva, M. B., \& Vershinina, E. A. (2009). Nekotorye normativy rechevogo razvitija detej ot 18 do 36 mesjacev (po materialam MakArturovskogo oprosnika) [Some norms of language development of children from 18 to 36 months]. Article presented at the Problems of Ontolinguistics Conference. Russia: Saint Petersburg.

Ellis, A. W., \& Morrison, C. M. (1998). Real age-of-acquisition effects in lexical retrieval. Journal of Experimental Psychology: Learning, Memory, and Cognition, 24, 515-523. doi:10.1037/0278-7393.24. 2.515

Eriksson, M., \& Berglund, E. (1999). Swedish early communicative development inventories: Words and gestures. First Language, 19, 55 90.

Fenson, L., Dale, P. S., Reznick, J. S., Thal, D., Bates, E., Hartung, J. P., . . . Reilly, J. S. (1993). The MacArthur Communicative Development Inventories. San Diego, CA: Singular.

Fenson, L., Reznick, J. S., Bates, E., Thal, D., \& Pethick, S. (1994). Variability in early communicative development. Monographs of the Society for Research in Child Development, 59(5, Serial No. 242)1-173.

Fenson, L., Marchman, V. A., Thal, D. J., Dale, P. S., Reznick, J. S., \& Bates, E. (2007). The MacArthur-Bates Communicative Development Inventories (2nd ed.). Baltimore: Brookes.

Ferrand, L., Bonin, P., Méot, A., Augustinova, M., New, B., Pallier, C., \& Brysbaert, M. (2008). Age-of-acquisition and subjective frequency estimates for all generally known monosyllabic French words and their relation with other psycholinguistic variables. Behavior Research Methods, 40, 1049-1054. doi:10.3758/BRM.40.4.1049

Garlock, V. M., Walley, A. C., \& Metsala, J. L. (2001). Age-of-acquisition, word frequency, and neighborhood density effects on spoken word recognition by children and adults. Journal of Memory and Language, 45, 468-492. doi:10.1006/jmla.2000.2784

Gerhand, S., \& Barry, C. (1999). Age of acquisition, word frequency, and the role of phonology in the lexical decision task. Memory \& Cognition, 27, 592-602. doi:10.3758/BF03211553

Ghyselinck, M., De Moor, W., \& Brysbaert, M. (2000). Age-ofacquisition ratings for 2816 Dutch four- and five-letter nouns. Psychologica Belgica, 40, 77-98.

Ghyselinck, M., Custers, R., \& Brysbaert, M. (2003). Age-of-acquisition rations for 2332 Dutch words from 49 different semantic categories. Psychologica Belgica, 43, 181-214.

Gilhooly, K. J., \& Gilhooly, M. L. M. (1980). The validity of age-ofacquisition ratings. British Journal of Psychology, 71, 105-110. doi:10.1111/j.2044-8295.1980.tb02736.x

Gilhooly, K. J., \& Hay, D. (1977). Imagery, concreteness, age-of-acquisition, familiarity, and meaningfulness values for 205 five-letter words having single-solution anagrams. Behavior Research Methods \& Instrumentation, 9, 12-17. doi:10.3758/BF03202210

Gilhooly, K. J., \& Logie, R. H. (1980). Age-of-acquisition, imagery, concreteness, familiarity, and ambiguity measures for 1,944 words. Behavior Research Methods \& Instrumentation, 12, 395-427. doi: 10.3758/BF03201693

González-Nosti, M., Barbón, A., Rodríguez-Ferreiro, J., \& Cuetos, F. (2014). Effects of the psycholinguistic variables on the lexical decision task in Spanish: A study with 2,765 words. Behavior Research Methods, 46, 517-525. doi:10.3758/s13428-013-0383-5

Grigoriev, A., \& Oshhepkov, I. (2013). Objective age of acquisition norms for a set of 286 words in Russian: Relationships with other psycholinguistic variables. Behavior Research Methods, 45, 12081217. doi:10.3758/s13428-013-0319-0

Haman, E., Łuniewska, M., \& Pomiechowska, B. (2015). Designing cross-linguistic lexical tasks (CLTs) for bilingual preschool children. In S. Armon-Lotem, J. de Jong, \& N. Meir (Eds.), Methods for assessing multilingual children: Disentangling bilingualism from Language impairment (pp. 194-238). Bristol: Multilingual Matters.

Havelka, J., \& Tomita, I. (2006). Age of acquisition in naming Japanese words. Visual Cognition, 13, 981-991. doi:10.1080/ 13506280544000156

Heilmann, J., Ellis Weismer, S., Evans, J., \& Hollar, C. (2005). Utility of the MacArthur-Bates Communicative Development Inventory in identifying language abilities of late-talking and typically developing toddlers. American Journal of Speech-Language Pathology, 14, 40-51.

Holmes, S. J., \& Ellis, A. W. (2006). Age of acquisition and typicality effects in three object processing tasks. Visual Cognition, 13, 884910. doi:10.1080/13506280544000093

Holmes, S. J., Fitch, F. J., \& Ellis, A. W. (2006). Age of acquisition affects object recognition and naming in patients with Alzheimer's disease. Journal of Clinical and Experimental Neuropsychology, 28, 1010 1022. doi:10.1080/13803390591004392

Iyer, G. K., Saccuman, C. M., Bates, E. A., \& Wulfeck, B. B. (2001). A study of age-of-acquisition (AoA) ratings in adults. Center for Research in Language Newsletter, 13(2). Retrieved from http://crl. ucsd.edu/experiments/ipnp/ref/Iyer2002CRL.pdf

Johnston, R. A., Dent, K., Humphreys, G. W., \& Barry, C. (2010). British-English norms and naming times for a set of 539 pictures: The role of age of acquisition. Behavior Research Methods, 42, 461-469. doi:10.3758/BRM.42.2.461

Jørgensen, R. N., Dale, P. S., Bleses, D., \& Fenson, L. (2009). CLEX: A cross-linguistic lexical norms database. Journal of Child Language, 37, 419-428

Jorm, A. F. (1991). The validity of word age-of-acquisition ratings: A longitudinal study of a child's word knowledge. British Journal of Developmental Psychology, 9, 437-444. doi:10.1111/j.2044-835X. 1991.tb00888.x

Juhasz, B. J. (2005). Age-of-acquisition effects in word and picture identification. Psychological Bulletin, 131, 684-712. doi:10.1037/00332909.131.5.684

Juhasz, B. J., \& Rayner, K. (2006). The role of age of acquisition and word frequency in reading: Evidence from eye fixation durations. Visual Cognition, 13, 846-863. doi:10.1080/13506280544000075

Khanna, M. M., \& Cortese, M. J. (2011). Age of acquisition estimates for 1,208 ambiguous and polysemous words. Behavior Research Methods, 43, 89-96. doi:10.3758/s13428-010-0027-y

Kittredge, A. K., Dell, G. S., Verkuilen, J., \& Schwartz, M. F. (2008). Where is the effect of frequency in word production? Insights from aphasic picture-naming errors. Cognitive Neuropsychology, 25, 463-492. doi:10.1080/02643290701674851

Kuperman, V., Stadthagen-Gonzalez, H., \& Brysbaert, M. (2012). Ageof-acquisition ratings for 30,000 English words. Behavior Research Methods, 44, 978-990. doi:10.3758/s13428-012-0210-4 
Kuvac Kraljevic, J., Cepanec, M., \& Kovacevic, M. (2009). Croatian lexical database (1st scale). Available at www.cdi-clex.org/ vocabulary/about/index/corpora/5

Lachman, R., Shaffer, J. P., \& Hennrikus, D. (1974). Language and cognition: Effects of stimulus codability, name-word frequency, and age of acquisition on lexical reaction time. Journal of Verbal Learning and Verbal Behavior, 13, 613-625. doi:10.1016/S00225371(74)80049-6

Laganaro, M., \& Perret, C. (2011). Comparing electrophysiological correlates of word production in immediate and delayed naming through the analysis of word age of acquisition effects. Brain Topography, 24, 19-29. doi:10.1007/s10548-010-0162-x

Lambon Ralph, M. A., \& Ehsan, S. (2006). Age of acquisition effects depend on the mapping between representations and the frequency of occurrence: Empirical and computational evidence. Visual Cognition, 13, 928-948. doi:10.1080/13506280544000110

Lind, M., Simonsen, H. G., Hansen, P., Holm, E., \& Mevik, B. H. (2015). Norwegian words: A lexical database for clinicians and researchers. Clinical Linguistics \& Phonetics, 29, 276-290. doi:10.3109/ 02699206.2014 .999952

Liu, Y., Shu, H., \& Li, P. (2007). Word naming and psycholinguistic norms: Chinese. Behavior Research Methods, 2, 192-198. doi:10. 3758/BF03193147

Liu, Y., Hao, M., Li, P., \& Shu, H. (2011). Timed picture naming norms for Mandarin Chinese. PLoS ONE, 6, e16505. doi:10.1371/journal. pone.0016505

Lotto, L., Surian, L., \& Job, R. (2010). Objective age of acquisition for 223 Italian words: Norms and effects on picture naming speed. Behavior Research Methods, 42, 126-133. doi:10.3758/BRM.42. 1.126

Lymperopoulou, O., Barry, C., \& Sakka, P. (2006). The effects of age of acquisition and word frequency on object naming accuracy in Alzheimer's disease. Annals of General Psychiatry, 5(1), S76.

Lyons, A. W., Teer, P., \& Rubenstein, H. (1978). Age-at-acquisition and word recognition. Journal of Psycholinguistic Research, 7, 179187.

Manoiloff, L., Artstein, M., Canavoso, M. B., Fernández, L., \& Segui, J. (2010). Expanded norms for 400 experimental pictures in an Argentinean Spanish-speaking population. Behavior Research Methods, 42, 452-460. doi:10.3758/BRM.42.2.452

Marques, J. F., Fonseca, F. L., Morais, S., \& Pinto, I. A. (2007). Estimated age of acquisition norms for 834 Portuguese nouns and their relation with other psycholinguistic variables. Behavior Research Methods, 39, 439-444. doi:10.3758/BF03193013

Meschyan, G., \& Hernandez, A. (2002). Age of acquisition and word frequency: Determinants of object-naming speed and accuracy. Memory \& Cognition, 30, 262-269. doi:10.3758/BF03195287

Mobaghan, J., \& Ellis, A. W. (2002). Age of acquisition and the completeness of phonological representations. Reading and Writing, 15, 759-788.

Moore, V., Smith-Spark, J., \& Valentine, T. (2004). The effects of age of acquisition on object perception. European Journal of Cognitive Psychology, 16, 417-439. doi:10.1080/09541440340000097

Moors, A., De Houwer, J., Hermans, D., Wanmaker, S., van Schie, K., Van Harmelen, A.-L., . . . Brysbaert, M. (2013). Norms of valence, arousal, dominance, and age of acquisition for 4,300 Dutch words. Behavior Research Methods, 45, 169-177. doi:10.3758/s13428012-0243-8

Moreno-Martínez, F. J., Montoro, P. R., \& Rodríguez-Rojo, I. C. (2014). Spanish norms for age of acquisition, concept familiarity, lexical frequency, manipulability, typicality, and other variables for 820 words from 14 living/nonliving concepts. Behavior Research Methods, 46, 1088-1097. doi:10.3758/s13428-013-0435-x

Morrison, C. M., \& Gibbons, Z. C. (2006). Lexical determinants of semantic processing speed. Visual Cognition, 13, 949-967. doi:10. 1080/13506280544000129
Morrison, C. M., Ellis, A. W., \& Quinlan, P. T. (1992). Age of acquisition, not word frequency, affects object naming, not object recognition. Memory \& Cognition, 20, 705-714. doi:10.3758/BF03202720

Morrison, C. M., Chappell, T. D., \& Ellis, A. W. (1997). Age of acquisition norms for a large set of object names and their relations to adult estimates and other variables. Quarterly Journal of Experimental Psychology, 50A, 528-559. doi:10.1080/027249897392017

Morrison, C. M., Hirsh, K. W., Chappell, T., \& Ellis, A. W. (2002). Age and age of acquisition: An evaluation of the cumulative frequency hypothesis. European Journal of Cognitive Psychology, 14, 435459. doi:10.1080/09541440143000159

Morrison, C. M., Hirsh, K. W., \& Duggan, G. B. (2003). Age of acquisition, ageing, and verb production: Normative and experimental data. Quarterly Journal of Experimental Psychology, 56A, 705730. doi:10.1080/02724980244000594

Navarrete, E., Scaltritti, M., Mulatti, C., \& Peressotti, F. (2013). Age-ofacquisition effects in delayed picture-naming tasks. Psychonomic Bulletin \& Review, 20, 148-153. doi:10.3758/s13423-012-0310-2

Nishimoto, T., Miyawaki, K., Ueda, T., Une, Y., \& Takahashi, M. (2005). Japanese normative set of 359 pictures. Behavior Research Methods, 37, 398-416. doi:10.3758/BF03192709

Nishimoto, T., Ueda, T., Miyawaki, K., Une, Y., \& Takahashi, M. (2012). The role of imagery-related properties in picture naming: A newly standardized set of 360 pictures for Japanese. Behavior Research Methods, 44, 934-945. doi:10.3758/s13428-011-0176-7

Pérez, M. A. (2007). Age of acquisition persists as the main factor in picture naming when cumulative word frequency and frequency trajectory are controlled. Quarterly Journal of Experimental Psychology, 60, 32-42. doi:10.1080/17470210600577423

Pérez, M. A., \& Navalon, C. (2005). Objective-AoA norms for 175 names in Spanish: Relationships with other psycholinguistic variables, estimated AoA, and data from other languages. European Journal of Cognitive Psychology, 17, 179-206.

Pind, J., Jónsdóttir, H., Gissurardóttir, H., \& Jónsson, F. (2000). Icelandic norms for the Snodgrass and Vanderwart (1980) pictures: Name and image agreement, familiarity, and age of acquisition. Scandinavian Journal of Psychology, 41, 41-48. doi:10.1111/1467-9450.00169

Piñeiro, A., \& Manzano, M. (2000). A lexical database for Spanishspeaking children. Behavior Research Methods, Instruments, \& Computers, 32, 616-628.

Raman, I. (2011). The role of age of acquisition in picture and word naming in dyslexic adults: Picture and word naming in dyslexia. British Journal of Psychology, 102, 328-339. doi:10.1348/ 000712610X522572

Raman, I., Raman, E., \& Mertan, B. (2014). A standardized set of 260 pictures for Turkish: Norms of name and image agreement, age of acquisition, visual complexity, and conceptual familiarity. Behavior Research Methods, 46, 588-595. doi:10.3758/s13428-013-0376-4

Rossion, B., \& Pourtois, G. (2004). Revisiting Snodgrass and Vanderwart's object pictorial set: The role of surface detail in basic-level object recognition. Perception, 33, 217-236. doi:10. $1068 / \mathrm{p} 5117$

Salmon, J. P., McMullen, P. A., \& Filliter, J. H. (2010). Norms for two types of manipulability (graspability and functional usage), familiarity, and age of acquisition for 320 photographs of objects. Behavior Research Methods, 42, 82-95. doi:10.3758/BRM.42.1.82

Schock, J., Cortese, M. J., Khanna, M. M., \& Toppi, S. (2012). Age of acquisition estimates for 3,000 disyllabic words. Behavior Research Methods, 44, 971-977. doi:10.3758/s13428-012-0209-x

Schröder, A., Gemballa, T., Ruppin, S., \& Wartenburger, I. (2011). German norms for semantic typicality, age of acquisition, and concept familiarity. Behavior Research Methods, 44, 380-394. doi:10. 3758/s13428-011-0164-y

Severens, E., Van Lommel, S., Ratinckx, E., \& Hartsuiker, R. J. (2005). Timed picture naming norms for 590 pictures in Dutch. Acta Psychologica, 119, 159-187. doi:10.1016/j.actpsy.2005.01.002 
Shao, Z., Roelofs, A., \& Meyer, A. S. (2014). Predicting naming latencies for action pictures: Dutch norms. Behavior Research Methods, 46, 274-283. doi:10.3758/s13428-013-0358-6

Sirois, M., Kremin, H., \& Cohen, H. (2006). Picture-naming norms for Canadian French: Name agreement, familiarity, visual complexity, and age of acquisition. Behavior Research Methods, 38, 300-306. doi:10.3758/BF03192781

Snodgrass, J. G., \& Vanderwart, M. (1980). A standardized set of 260 pictures: Norms for name agreement, image agreement, familiarity, and visual complexity. Journal of Experimental Psychology: Human Learning and Memory, 6, 174-215. doi:10.1037/02787393.6.2.174

Snodgrass, J. G., \& Yuditsky, T. (1996). Naming time for the Snodgrass and Vanderwart pictures. Behavior Research Methods, Instruments, \& Computers, 28, 516-536. doi:10.3758/BF03200540

Spataro, P., Longobardi, E., Saraulli, D., \& Rossi-Arnaud, C. (2013). Interactive effects of age-of-acquisition and repetition priming in the lexical decision task: A multiple-loci account. Experimental Psychology, 60, 235-242. doi:10.1027/1618-3169/a000192

Stadthagen-Gonzalez, H., \& Davis, C. J. (2006). The Bristol norms for age of acquisition, imageability, and familiarity. Behavior Research Methods, 38, 598-605. doi:10.3758/BF03193891

Stadthagen-Gonzalez, H., Bowers, J. S., \& Damian, M. F. (2004). Ageof-acquisition effects in visual word recognition: Evidence from expert vocabularies. Cognition, 93, B11-B26. doi:10.1016/j. cognition.2003.10.009

Stadthagen-Gonzalez, H., Damian, M. F., Pérez, M. A., Bowers, J. S., \& Marín, J. (2009). Name-picture verification as a control measure for object naming: A task analysis and norms for a large set of pictures. Quarterly Journal of Experimental Psychology, 62, 1581-1597. doi: 10.1080/17470210802511139

Stration, R. P., Jacobus, K. A., \& Brinley, B. (1975). Age-of-acquisition, imagery, familiarity and meaningfulness norms for 543 words. Behavior Research Methods \& Instrumentation, 7, 1-6.

Szagun, G., Stumper, B., \& Schramm, A. S. (2009). Fragebogen zur frühkindlichen Sprachentwicklung (FRAKIS) und FRAKIS-K (Kurzform). Frankfurt: Pearson Assessment.
Thai, D. J., O’Hanlon, L., Clemmons, M., \& Fralin, L. (1999). Validity of a parent report measure of vocabulary and syntax for preschool children with language impairment. Journal of Speech, Language, and Hearing Research, 42, 482-496.

Thordardottir, E. T., \& Ellis Weismer, S. (1996). Language assessment via parent report: Development of a screening instrument for Icelandic children. First Language, 16, 265-285. doi:10.1177/ 014272379601604801

Tsaparina, D., Bonin, P., \& Méot, A. (2011). Russian norms for name agreement, image agreement for the colorized version of the Snodgrass and Vanderwart pictures and age of acquisition, conceptual familiarity, and imageability scores for modal object names. Behavior Research Methods, 43, 1085-1099. doi:10.3758/s13428011-0121-9

Turner, J. E., Valentine, T., \& Ellis, A. W. (1998). Contrasting effects of age of acquisition and word frequency on auditory and visual lexical decision. Memory \& Cognition, 26, 1282-1291. doi:10.3758/ BF03201200

Vinson, D. P., Cormier, K., Denmark, T., Schembri, A., \& Vigliocco, G. (2008). The British Sign Language (BSL) norms for age of acquisition, familiarity, and iconicity. Behavior Research Methods, 40, 1079-1087. doi:10.3758/BRM.40.4.1079

Walley, A. C., \& Metsala, J. L. (1992). Young children's age-ofacquisition estimates for spoken words. Memory \& Cognition, 20, 171-182. doi:10.3758/BF03197166

Wilson, M. A., Ellis, A. W., \& Burani, C. (2012). Age-of-acquisition affects word naming in Italian only when stress is irregular. Acta Psychologica, 139, 417-424.

Wilson, M. A., Cuetos, F., Davies, R., \& Burani, C. (2013). Revisiting age-of-acquisition effects in Spanish visual word recognition: The role of item imageability. Journal of Experimental Psychology: Learning, Memory, and Cognition, 39, 1842-1859. doi:10.1037/ a0033090

Winters, J. J., Jr., Winter, L., \& Burger, A. L. (1978). Confidence in ageof-acquisition estimates and its relationship to children's labeling performance. Bulletin of the Psychonomic Society, 12, 361-364. 